\title{
The transport and mass balance of fallout radionuclides in Brotherswater, Cumbria (UK)
}

\author{
P. G. Appleby (1) • P. Semertzidou • G. T. Piliposian • R. C. Chiverrell • \\ D. N. Schillereff $\cdot$ J. Warburton
}

Received: 11 February 2019/Accepted: 11 September 2019/Published online: 27 September 2019

(C) The Author(s) 2019

\begin{abstract}
This paper investigates the role of intervening transport processes on lake sediment records of the atmospherically deposited radionuclides ${ }^{210} \mathrm{~Pb}$ and ${ }^{137}$ Cs. Brotherswater is of particular interest to this issue in that its large catchment/lake area ratio and short water residence time are likely to amplify the influence of these processes, both from the catchment and through the water column. Brotherswater is also unique in being the site of two earlier multicore studies that, together with the present study, span a period of 4 decades. Measurements of fallout radionuclides were made on soil cores, suspended sediments and sediment
\end{abstract}

Electronic supplementary material The online version of this article (https://doi.org/10.1007/s10933-019-00095-z) contains supplementary material, which is available to authorized users.

P. G. Appleby $(\bowtie) \cdot$ P. Semertzidou · G. T. Piliposian Environmental Radioactivity Research Centre, Department of Mathematical Sciences, University of Liverpool, Liverpool, UK

e-mail: appleby@liv.ac.uk

\section{R. C. Chiverrell}

School of Environmental Sciences, University of Liverpool, Roxby Building, Liverpool, UK

D. N. Schillereff

Department of Geography, King's College London, London WC2B 4BG, UK

J. Warburton

Department of Geography, Durham University, Durham, UK cores, and the results combined with those from earlier studies to construct mass balances for ${ }^{210} \mathrm{~Pb}$ and ${ }^{137} \mathrm{Cs}$ in Brotherswater. The results showed that catchment inputs accounted for $63 \%$ of ${ }^{210} \mathrm{~Pb}$ entering the lake. Further, just $47 \%$ of ${ }^{210} \mathrm{~Pb}$ entering the water column was delivered to the sediment record. For comparison, in an earlier study at nearby Blelham Tarn with a relatively smaller catchment but longer water residence time it was shown that $47 \%$ of ${ }^{210} \mathrm{~Pb}$ inputs were delivered via the catchment, $75 \%$ of which were delivered to the sediment record. Results from both sites suggest that ${ }^{210} \mathrm{~Pb}$ is predominantly transported on fine particulates with a mean particle size of 3-4 $\mu \mathrm{m}$. Their relatively slow removal from the water column allows them to be transported relatively uniformly throughout the lake and may help account for the fact that simple ${ }^{210} \mathrm{~Pb}$ dating models are relatively reliable in spite of the complexities of the transport processes. Mass balance calculations for ${ }^{137} \mathrm{Cs}$ are more complicated because of the variable fallout record. Measurements of ${ }^{137} \mathrm{Cs}$ in the input stream and water column showed that catchment inputs are still significant 30 years after the last significant fallout (Chernobyl). Modelled results showed that catchment inputs delayed the date of peak inputs of weapons test fallout to the lake though by no more than 2 years. Although the results presented here are primarily concerned with fallout radionuclides and their reliability for dating, they also have implications for the use of sediment archives in reconstructing historical records of other 
atmospherically deposited substances such as trace metals or persistent organic pollutants.

Keywords ${ }^{210} \mathrm{~Pb} \cdot{ }^{137} \mathrm{Cs} \cdot$ Mass balance .

Brotherswater - Catchment - Lake sediments .

Radiometric dating

\section{Introduction}

In spite of their relevance to paleolimnology, there have been relatively few detailed studies of the pathways by which atmosphere contaminants deposited on the landscape are delivered to the sediment records at the bed of a lake. For the most part it is assumed that accumulating sediments provide at the very least a good qualitative record of atmospheric fallout. A more detailed understanding of transport pathways is of particular relevance to records of the fallout radionuclides ${ }^{210} \mathrm{~Pb}$ and ${ }^{137} \mathrm{Cs}$ used to date sediments. The widely used $\mathrm{CRS}{ }^{210} \mathrm{~Pb}$ dating model (Appleby and Oldfield 1978; Robbins 1978) assumes that a relatively constant (on yearly timescales) atmospheric flux is reflected in a constant rate of supply of ${ }^{210} \mathrm{~Pb}$ to the sediments. Chronostratigraphic dating by ${ }^{137} \mathrm{Cs}$ matches features in the ${ }^{137} \mathrm{Cs}$ activity versus depth record with the known historical fallout record. Both assumptions are potentially questionable at sites where a significant fraction of the supply to the sediment record consists of older catchment derived material that may have been deposited years or even decades earlier. A further uncertainty is the extent to which inputs to the water column are lost via the outflow.

A mass balance study of ${ }^{210} \mathrm{~Pb}$ in the water column of Bickford Pond (Massachusetts, USA) carried out by Benoit and Hemond (1987) based on measurements of ${ }^{210} \mathrm{~Pb}$ concentrations in inlet streams and the water column suggested that around $40 \%$ of ${ }^{210} \mathrm{~Pb}$ delivered to the water column did so indirectly from the catchment. In this particular case, since around $46 \%$ of total inputs were lost from the lake via the outflow, the amount of ${ }^{210} \mathrm{~Pb}$ delivered to the sediment record was comparable to the direct atmospheric flux. Nonetheless their results do highlight the potential influence catchment inputs may have on the timing of the supply rate and its distribution over the bed of the lake. Catchment inputs of ${ }^{210} \mathrm{~Pb}$ to Lake Geneva from the alpine Rhone watershed (Dominik et al. 1987) were found to be relatively less significant, just $17 \%$ of total inputs. A contributory factor to the lower figure here may be the smaller catchment/lake area ratio $(\sim 9)$ compared to Bickford Pond $(\sim 20)$. In a more recent study (Appleby et al. 2003) of transport pathways at Blelham Tarn (English Lake District, catchment/lake area ratio $\sim 42$ ), catchment inputs were estimated to represent around $47 \%$ of total ${ }^{210} \mathrm{~Pb}$ inputs to the lake. These inputs were however concentrated near one of the major input streams. Away from this part of the lake, the sediment record was dominated by direct atmospheric fallout, though the detailed pattern was influenced by sediment focussing.

The purpose of the present study was to investigate the transport processes controlling the fate of fallout radionuclides deposited on the catchment of Brotherswater in the English Lake District, and in particular the impact of those processes on the supply of ${ }^{210} \mathrm{~Pb}$ and ${ }^{137} \mathrm{Cs}$ to the sediment record in the lake. Because of its large catchment/lake area ratio and small water residence time the impacts are likely to be much more visible at Brotherswater compared to other northern temperate lake systems.

Brotherswater is unique in that it has been the subject of a number of detailed studies spanning a period of 4 decades, the first of which was carried out in the late 1970s (Eakins et al. 1981, 1984). As well as investigating the potential applications of ${ }^{210} \mathrm{~Pb}$ and ${ }^{137} \mathrm{Cs}$ for dating sediment records, this pioneering study by John Eakins and Roger Cambray (AERE Harwell) also considered the source of these radionuclides and the pathways by which they entered the sediment record. Atmospheric deposition was measured directly via the analysis of rainwater samples collected monthly from a site near the lake, and indirectly via soil cores collected from various locations in the catchment. Further analyses were carried out on lake and stream water samples collected on several occasions during the study period, and on sediment cores from different locations within the lake. Their conclusion that ${ }^{210} \mathrm{~Pb}$ enters the water column predominantly (93\%) via transport from the catchment appears however to greatly overestimate the significance of this pathway, largely due to an assumption that sediments entering the lake via the main inflow, including those during flood events $(90 \%$ of the total), had ${ }^{210} \mathrm{~Pb}$ concentrations similar to those 
on fine sediments in the water column. From this assumption they concluded that inputs of ${ }^{210} \mathrm{~Pb}$ to the lake amounted to $15 \mathrm{mCi}$ year $^{-1}\left(1 \mathrm{mCi}=3.7 \times 10^{7}\right.$ $\mathrm{Bq})$, of which just $1.1 \mathrm{mCi}^{-y_{e}{ }^{-1}}(7 \%)$ were attributable to direct fallout onto the lake. Further, just $14 \%$ of total inputs $\left(2.1 \mathrm{mCi}^{\text {year }}{ }^{-1}\right)$ were incorporated in the sediment record, the remainder $\left(12.9 \mathrm{mCi}_{\text {year }}{ }^{-1}\right)$ being lost via the outlet. Direct estimates based on their own measured concentrations in lake and stream water samples (Eakins et al. 1981, 1984) suggest a much lower figure of between 1.5 and $2.5 \mathrm{mCi}^{\text {year }}{ }^{-1}$ for losses via the outflow, and in consequence a much lower figure for catchment inputs.

A second multi-core study at Brotherswater was carried out in the late 1980s and early 1990s as part of an investigation into the fate of fallout radionuclides deposited as a result of the 1986 Chernobyl accident (Bonnett et al. 1992; Hilton et al. 1992). Sediment records of the short-lived radionuclide ${ }^{134} \mathrm{Cs}$ characteristic of Chernobyl fallout, as well as ${ }^{210} \mathrm{~Pb}$ and ${ }^{137} \mathrm{Cs}$, were determined in six lake sediment cores from sites similar to those sampled in the 1976/77 study. Soil cores from six different locations across the catchment were used to quantify atmospheric fallout. A further suite of six soil cores were collected in November 1991 from a flat site adjacent to the lake as part of a separate study of ${ }^{210} \mathrm{~Pb}$ and ${ }^{137} \mathrm{Cs}$ fallout in Cumbria (Smith et al. 1997).

Brotherswater has also been the subject of a number of projects concerned with hydrological and sedimentological issues. In the 1970s Chambers (1978) carried out regular measurements of fluvial discharges into and out of the lake over a 2-year period (1975-1977), and suspended sediment inputs over a 1-year period (1976-1977). More recently (2012-2013) sediment traps were deployed to measure sediment fluxes through the water column of Brotherswater (Schillereff et al. 2016a). In the wake of Storm Desmond (December 2015), suspended sediments entering the lake have been monitored using sediment traps placed near the mouths of the main inlet stream.

In the first part of the present study, ${ }^{210} \mathrm{~Pb}$ and ${ }^{137} \mathrm{Cs}$ records in a suite of sediment cores from Brotherswater collected during 2011-2016 were compared with those from earlier studies in order to carry out an assessment of their long-term stability and reliability as dating tools. It was evident from the results (Semertzidou et al. 2019) that fallout records in certain parts of the lake were strongly influenced by catchment inputs and that in some cases these had a significant bearing on the choice of dating model. The object of this paper is to present a more detailed account of the extent to which sediment records are impacted by catchment inputs, and also the influence on those records of losses from the lake via the outflow. Radiometric analyses carried out on soil cores, suspended sediments and bottom sediments, together with data from the earlier studies are used to establish more accurate mass balance models for both ${ }^{210} \mathrm{~Pb}$ and ${ }^{137} \mathrm{Cs}$ in Brotherswater. This is relatively straightforward for ${ }^{210} \mathrm{~Pb}$ where in the absence of major catchment disturbances inputs and outputs on yearly timescales can reasonably be assumed to be in a steady state. The situation for ${ }^{137} \mathrm{Cs}$ is more complicated because of its varying atmospheric flux. Global fallout from the atmospheric testing of nuclear weapons effectively began around 1953, reached a peak in 1963, and then declined rapidly following the implementation of the test ban treaty in that year. By the early 1980s it had fallen to negligible levels. Many European sites, including Brotherswater, were also subject to fallout from the Chernobyl reactor fire in 1986. Up to then, annual inputs of ${ }^{137} \mathrm{Cs}$ to the water column will have included both contemporary fallout onto the lake, and indirect inputs via the catchment consisting of ${ }^{137} \mathrm{Cs}$ deposited over a range of years since 1953. Inputs after 1986 consist solely of catchment derived material. Data from the different studies (1976/77, 1988/89, and 2011/16) can be used to establish mass balances for ${ }^{137} \mathrm{Cs}$ at each of those times. From the results, simple models of transport processes from the catchment (Appleby et al. 2003) and through the water column (Appleby 1997) can be used to model the historical relationship between atmospheric fallout and inputs to the sediment record, and how this might change in the future. Catchment/ lake transport parameters for ${ }^{210} \mathrm{~Pb}$ and ${ }^{137} \mathrm{Cs}$ at Brotherswater are compared with values obtained from several other studies with a view to using these models for making estimates of catchment inputs at sites studied in less detail based on a small number of physiographic parameters such as mean annual rainfall, catchment/lake area ratio, and water residence time. 
The study site

Brotherswater is a small $\left(0.18 \mathrm{~km}^{2}\right)$, upland (altitude $158 \mathrm{~m}$ ) lake in the Hartsop valley, in Cumbria, N.W.England, about $13 \mathrm{~km}$ north of Windermere. It has a large catchment $\left(13 \mathrm{~km}^{2}\right)$ and large catchmentto-lake area ratio (72) (Schillereff et al. 2016b). The catchment drains northwards by way of a several small becks that merge to form a single stream (Kirkstone Beck) that discharges into the lake near its southwestern corner. In recent times it had a single input channel, up until 2014-2015 when a second channel was formed. The outlet stream, Goldrill Beck, is located at the north-western corner of the lake and drains northwards towards Ullswater. The bathymetry of the lake (Fig. 1) is dominated by a central flat profundal zone with a maximum depth of $18 \mathrm{~m}$. A recent more accurate survey (Schillereff et al. 2019) has determined the lake volume to be $1.33 \times 10^{6} \mathrm{~m}^{3}$, and the mean depth $7.8 \mathrm{~m}$.

\section{Methods}

Atmospheric deposition

Fallout can be determined directly using bulk deposition collectors, or indirectly using soil cores as natural long-term collectors. Direct measurements have in the past been made at Brotherswater (1976/77,
Fig. 1 Brotherswater showing the location and bathymetry of the lake, sediment coring sites from both the present and earlier studies, and the locations of the sediment traps (Trap A and Trap B)

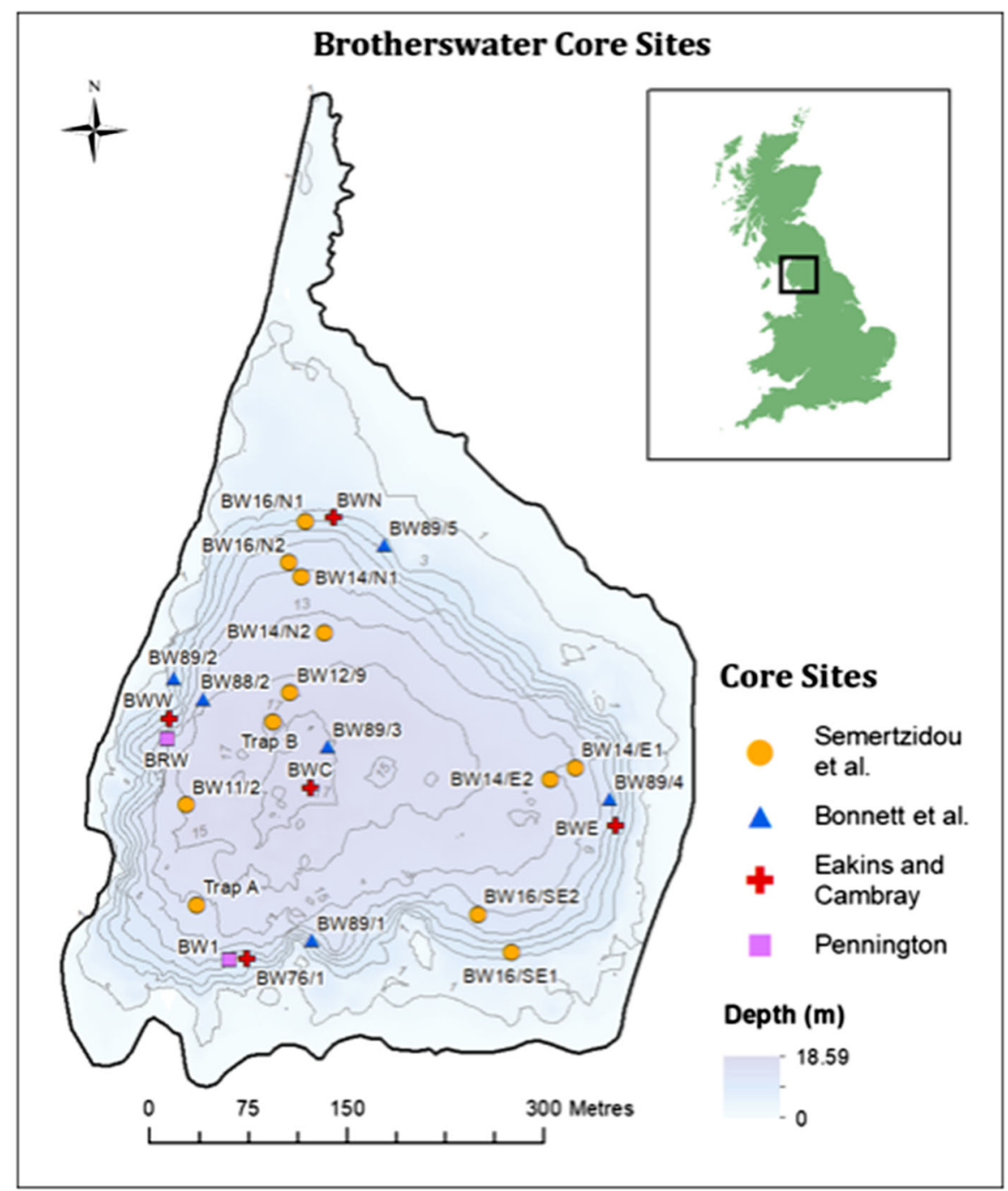


Eakins et al. 1981, 1984), and also at nearby Esthwaite Water (1997/98, Appleby et al. 2003). Indirect measurements from soil cores were made during each of the 1976/77, 1988/89 and 1991 studies. To support these earlier studies, further measurements were made of ${ }^{210} \mathrm{~Pb}$ and ${ }^{137} \mathrm{Cs}$ records in soil cores from two sites in the Brotherswater catchment (Fig. 2) selected as far as possible according to the criteria

- There should have been no major soil disturbance for at least 30 years,

- Soils should be of a type that inhibits radionuclide migration through the soil column,
- They should be on open level ground not subject to erosion or flooding by surface waters,

- The soils should be relatively compact and saturated (to minimise in situ ${ }^{222} \mathrm{Rn}$ escape),

- The soil depth should be sufficient to contain the entire fallout inventory.

Transport of radionuclides from the catchment to the lake

Sediment samples collected using Time-Integrated Mass-flux Sampler (TIMS, Perks et al. 2013) sediment
Fig. 2 Part of the

Brotherswater catchment showing the soil core sites

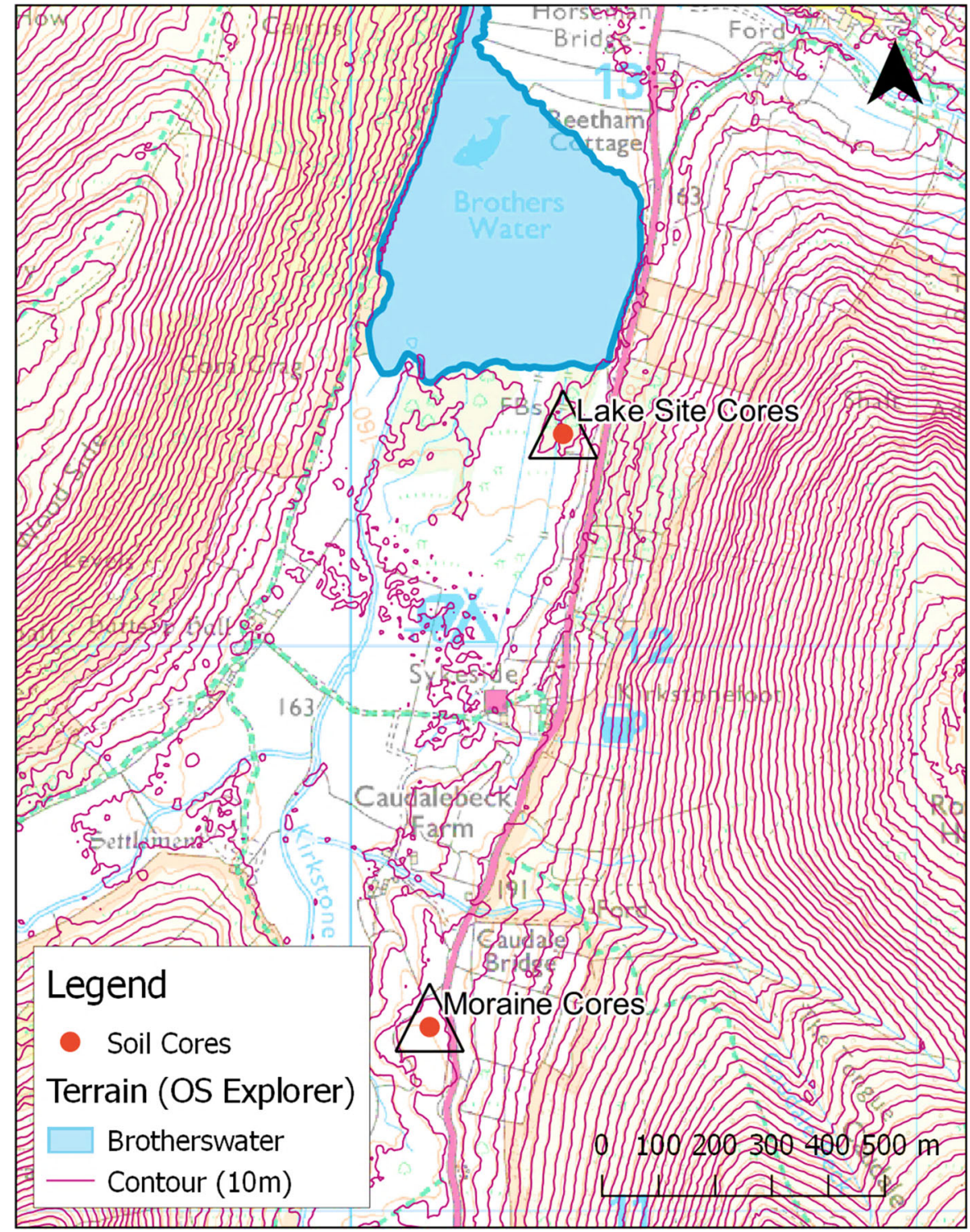


traps placed in both channels of the inflow stream close to its mouth were analysed for ${ }^{210} \mathrm{~Pb}$ and ${ }^{137} \mathrm{Cs}$. The traps were deployed and collected at 2-3 month intervals over a period of 16 months, from July 2016 through to October 2017. Samples included both fine sediments collected during periods of relatively normal flow and coarser material collected during flood events.

Radionuclide fluxes through the water column

Sediment samples collected in traps placed in the water column were analysed for ${ }^{210} \mathrm{~Pb}$ and ${ }^{137} \mathrm{Cs}$. The traps (Schillereff et al. 2016a) consisted of pairs of 11-cm-diameter cylindrical PVC tubes with a 1:8 (width:depth) aspect ratio and removable basal sampling cups (Bloesch and Burns 1980) placed at three different levels, $25 \%, 75 \%$ and $100 \%$ of water depth. They were deployed at two different locations in the lake (Fig. 1):

- Site A near the delta (75 $\mathrm{m}$ from the inflow) in $\sim 12 \mathrm{~m}$ water depth,

- Site B near the central area of the lake in $\sim 17 \mathrm{~m}$ water depth.

Samples were collected at intervals of 1-2-months over a 17-month period, from August 2012 to December 2013 (Schillereff et al. 2016a) and analysed for ${ }^{210} \mathrm{~Pb}$ and ${ }^{137} \mathrm{Cs}$. Sediment masses accumulating during each collection period were used to calculate ${ }^{210} \mathrm{~Pb}$ and ${ }^{137} \mathrm{Cs}$ fluxes through the water column.

Sediment records of fallout radionuclides

A total of 10 new sediment cores were collected from the bed of the lake during the period 2011-2016 using a short $8 \mathrm{~cm}$ diameter gravity corer designed to capture an intact sediment-water interface (Boyle 1995) and analysed for ${ }^{210} \mathrm{~Pb}$ and ${ }^{137} \mathrm{Cs}$. Figure 1 also shows their locations, together with those of cores collected during the earlier 1970s and 1980s studies. Map coordinates and water depths for the new cores are given in Semertzidou et al. (2019).

\section{Radiometric analyses}

Dried sediment samples from the traps and cores were analysed for ${ }^{210} \mathrm{~Pb},{ }^{226} \mathrm{Ra},{ }^{137} \mathrm{Cs}$ and ${ }^{241} \mathrm{Am}$ by direct gamma assay in the Liverpool University ERL
(Environmental Radioactivity Laboratory) using Ortec HPGe GWL series well-type coaxial low background intrinsic germanium detectors (Appleby et al. 1986). Samples were placed in 5-cm-long by 1-cm-diameter nylon sample tubes sealed with flanged rubber Suba-Seals dipped in paraffin wax to prevent ${ }^{222} \mathrm{Rn}$ escape. ${ }^{210} \mathrm{~Pb}$ was determined via its gamma emissions at $46.5 \mathrm{keV}$, and ${ }^{226} \mathrm{Ra}$ by the $295 \mathrm{keV}$ and $352 \mathrm{keV} \gamma$-rays emitted by its daughter isotope ${ }^{214} \mathrm{~Pb}$ following 3 weeks storage to allow ${ }^{214} \mathrm{~Pb} /{ }^{226} \mathrm{Ra}$ radioactive equilibration. ${ }^{137} \mathrm{Cs}$ and ${ }^{241} \mathrm{Am}$ were measured by their emissions at $661.7 \mathrm{keV}$ and $59.5 \mathrm{keV}$ respectively. Absolute efficiencies of the detectors were determined using calibrated sources and sediment samples of known activity. Corrections were made for the effect of self-absorption of low energy $\gamma$-rays within the sample (Appleby et al. 1992), and for background radiation from the detectors themselves. Background counts of 60-h duration were carried out on each detector at regular intervals. Mean background count rates were typically around $0.5 \mathrm{cph}$ (counts per hour) for the $46.5 \mathrm{keV}$ peak and $1 \mathrm{cph}$ for the $661.7 \mathrm{keV}$ peak. An Ortec GMX series coaxial detector with similar characteristics was used for measuring larger soil core samples.

All values are relative to the date of sampling unless stated otherwise. Uncertainties have been calculated from the counting statistics.

\section{Data analysis and modelling}

Data from all three studies were assessed for their consistency and reliability and combined where appropriate. The results were used to construct mass balances for fallout radionuclides in the water column of Brotherswater detailing total inputs via direct fallout and catchment transport, and total outputs via delivery to the sediment record and losses via the outflow. Catchment/lake transport rates were used to calculate values of the ${ }^{210} \mathrm{~Pb}$ and ${ }^{137} \mathrm{Cs}$ transport parameters for Brotherswater for the catchment/lake model developed in Appleby et al. (2003). 


\section{Results}

Atmospheric deposition

\section{Mean annual ${ }^{210} \mathrm{~Pb}$ flux}

Direct measurements of fallout of ${ }^{210} \mathrm{~Pb}$ on a near monthly basis were carried out at Brotherswater by Eakins et al. (1981, 1984) during a 12-month period from November 1976 to October 1977. Since the rainfall total during that period $(2108 \mathrm{~mm})$ was significantly below average, in estimating the mean annual ${ }^{210} \mathrm{~Pb}$ flux a correction to the amount of fallout ${ }^{210} \mathrm{~Pb}$ collected $\left(148 \mathrm{~Bq} \mathrm{~m}^{-2}\right.$ ) was made by assuming it to be proportional to rainfall. Using a revised estimate of the mean annual rainfall at Brotherswater (2609 $\mathrm{mm} \mathrm{year}^{-1}$ ) based on an updated analysis of data from nearby sites (Grisedale Bridge, Brotherswater Inn, Harstop Hall, Hartsop Village), the mean atmospheric ${ }^{210} \mathrm{~Pb}$ flux at Brotherswater is calculated to be $183 \mathrm{~Bq} \mathrm{~m}^{-2}$ year $^{-1}$.

In an alternative approach, measurements carried out at Esthwaite Water (10 miles to the south west) during a 16-month period from April 1997 to July 1998 showed a broadly linear relationship between monthly ${ }^{210} \mathrm{~Pb}$ deposition and monthly rainfall (Appleby et al. 2003). An analysis of the Brotherswater data shows that they follow a similar relationship with broadly similar values for the linear coefficients. Applying these relationships to the mean annual rainfall yields values for the ${ }^{210} \mathrm{~Pb}$ flux of between 177 and $188 \mathrm{~Bq} \mathrm{~m}^{-2}$ year $^{-1}$.

The fallout ${ }^{210} \mathrm{~Pb}$ inventory $A_{\mathrm{o}}$ in a soil core acting as a long-term collector is related to the mean atmospheric flux $P$ by the equation

$P=\lambda A_{0}$.

Values of the ${ }^{210} \mathrm{~Pb}$ inventories and the corresponding ${ }^{210} \mathrm{~Pb}$ fluxes for soil cores from (a) the $1976 / 77$ study, (b) the 1991 study and (c) the 20105/16 study are given in Electronic Supplementary Material ESM1. Mean values calculated from both the individual core values and mean site values range from 183 to $186 \mathrm{~Bq} \mathrm{~m}^{-2}$ year $^{-1}$. These are consistent with estimates based on the direct fallout measurements. From all the data a best estimate of the mean annual ${ }^{210} \mathrm{~Pb}$ flux at Brotherswater is therefore $183 \pm 5 \mathrm{~Bq} \mathrm{~m}^{-2}$ year $^{-1}$.

${ }^{137} \mathrm{Cs}$ fallout record
Results of the ${ }^{137} \mathrm{Cs}$ measurements, summarised in ESM2, include both raw inventories (where available) and values decay corrected to 1986 . The raw inventories from the 1976/77 study are essentially those published in Eakins et al. $(1981,1984)$ though for the two Delta sites only the mean value has been given. The decay corrected inventories include a small adjustment for the fact that weapons test fallout at the time of the 1976/77 study was incomplete. Weapons test fallout data (Cambray et al. 1989) suggest that post-1977 fallout would have contributed a further $3.25 \%$ to the total inventory.

Pre-1986 soil cores contained ${ }^{137} \mathrm{Cs}$ that derived solely from weapons fallout. This had fallen to negligible values by the early 1980s. Choosing 1986, the year of the Chernobyl accident, as a common reference date, results from the 1976/77 cores indicated that total fallout from this source at Brotherswater decay corrected to 1986 amounted to $7886 \mathrm{~Bq} \mathrm{~m}^{-2}$. This is in good agreement with the value calculated from the results of a detailed survey of weapons fallout in the UK carried out by Cawse and Horrill (1986). Using a least squares fit to the data presented in that survey, the cumulative weapons fallout inventory at any site (decay corrected to 1986) can be estimated using the relation

$I_{C s}=2.494 R+825$

where $R$ is the mean annual rainfall in $\mathrm{mm} \mathrm{year}^{-1}$. From this formula, the Brotherswater weapons ${ }^{137} \mathrm{Cs}$ fallout inventory (mean annual rainfall $2609 \mathrm{~mm} \mathrm{year}^{-1}$ ) is calculated to be $7333 \mathrm{~Bq} \mathrm{~m}^{-2}$. The average value by these two methods, $7610 \mathrm{~Bq} \mathrm{~m}^{-2}$, represents a best estimate of the cumulative fallout of nuclear weapons test fallout at Brotherswater, decay corrected to 1986 . The historical record (decay corrected to 1986) can be reconstructed by an appropriate scaling of the history of weapons test fallout in the northern hemisphere given e.g. in Cambray et al. (1989). The results indicate that by the time of the 1976/77 study fallout had declined to around $50 \mathrm{~Bq} \mathrm{~m}^{-2}$. This is consistent with the empirical value of $61 \mathrm{~Bq} \mathrm{~m}^{-2}$ calculated from the data obtained by Eakins et al. (1981).

The much higher ${ }^{137} \mathrm{Cs}$ inventories in post-1986 soil cores (other than those from the 1989 study) are attributable to fallout from the Chernobyl accident in April/May 1986. Results from the 1989 study were 
clearly flawed in that they yielded ${ }^{137} \mathrm{Cs}$ inventories significantly lower than those determined from the 1976/77 study. Results from the present study are in good agreement with those from the 1991 study. Excluding the values from cores BWSC16/1 and BWSC16/2 where the records were evidently not complete, the mean value from both these studies is $11,611 \mathrm{~Bq} \mathrm{~m}^{-2}$. Subtracting the 1986 weapons fallout inventory, fallout of ${ }^{137} \mathrm{Cs}$ at Brotherswater due to Chernobyl is calculated to be $4001 \mathrm{~Bq} \mathrm{~m}^{-2}$. This value is consistent with the estimate made by Smith and Clarke (1989) that levels of Chernobyl ${ }^{137} \mathrm{Cs}$ deposition in the Brotherswater catchment were between 2000 and $5000 \mathrm{~Bq} \mathrm{~m}^{-2}$.

Radionuclide concentrations on input stream sediments

Table 1 summarises the results of measurements of fallout ${ }^{210} \mathrm{~Pb}$ and ${ }^{137} \mathrm{Cs}$ in sediment samples from TIMS traps placed in the input stream close to its mouths. Unsupported ${ }^{210} \mathrm{~Pb}$ concentrations varied widely from as little as $13 \mathrm{~Bq} \mathrm{~kg}^{-1}$ to more than $200 \mathrm{~Bq} \mathrm{~kg}^{-1}$. The mean concentration of around $82 \mathrm{~Bq} \mathrm{~kg}^{-1}$ is just $20 \%$ of the value assumed by Eakins et al. (1981, 1984). The samples referred to in this table mainly consisted of sediments collected during periods of relatively normal flow. Sediments transported during flood events include large quantities of relatively coarse material containing relatively

Table $1{ }^{210} \mathrm{~Pb}$ and ${ }^{137} \mathrm{Cs}$ concentrations on sediment samples from TIMS traps placed in the main Brotherswater inflow streams

\begin{tabular}{llllll}
\hline Date & \multicolumn{2}{l}{ Unsupported $^{210} \mathrm{~Pb}$} & & \multicolumn{2}{l}{${ }^{137} \mathrm{Cs}$} \\
\cline { 2 - 3 } \cline { 6 - 6 } & $\mathrm{Bq} \mathrm{kg}^{-1}$ & \pm & & $\mathrm{Bq} \mathrm{kg}^{-1}$ & \pm \\
\hline Jul-16 & 110 & 18 & & 39 & 5 \\
Aug-16 & 65 & 16 & & 20 & 4 \\
Oct-16a & 80 & 21 & & 26 & 5 \\
Oct-16b & 13 & 5 & & 12 & 1 \\
Jul-17 & 73 & 34 & & 25 & 4 \\
Oct-17a & 216 & 53 & & 42 & 7 \\
Oct-17b & 18 & 2.4 & & 12 & 1 \\
Mean & 82 & 10 & & 25 & 2 \\
& $109^{\mathrm{a}}$ & 14 & & $30^{\mathrm{a}}$ & 2 \\
\hline
\end{tabular}

${ }^{\mathrm{a}}$ Excluding the two coarse-grained samples from October $2016 \mathrm{~b}$ and October $2017 \mathrm{~b}$ little ${ }^{210} \mathrm{~Pb}$, as seen in the October $2016 \mathrm{~b}$ and October 2017b samples. Excluding these, the mean unsupported ${ }^{210} \mathrm{~Pb}$ concentration on the remaining mainly fine-grained material was around $109 \mathrm{~Bq} \mathrm{~kg}^{-1} \cdot{ }^{137} \mathrm{Cs}$ concentrations were significantly lower and varied less widely, ranging between 12 and $42 \mathrm{~Bq} \mathrm{~kg}^{-1}$ with a mean value of around $25 \mathrm{~Bq} \mathrm{~kg}^{-1}$. Lowest concentrations were again recorded in the October $2016 \mathrm{~b}$ and October 2017b samples.

Radionuclide concentrations in and fluxes through the water column

ESM3 gives unsupported ${ }^{210} \mathrm{~Pb}$ and ${ }^{137} \mathrm{Cs}$ concentrations in sediments from the water column of Brotherswater on samples from the top, middle and basal collection tubes for (a) Trap A and (b) Trap B over each of the seven collection periods, spanning a total of 16 months. Table 2 shows mean ${ }^{210} \mathrm{~Pb}$ and ${ }^{137} \mathrm{Cs}$ concentrations for each collection tube over the entire period. Significantly higher concentrations compared to those in sediments from the input stream can be attributed to removal of coarse-grained material in the delta zone adjacent to the mouth of the input stream. The impact of this process is further reflected by the higher concentrations in Trap B located in the centre of the lake compared to those at Trap A near the delta.

ESM3 also gives sediment, ${ }^{210} \mathrm{~Pb}$ and ${ }^{137} \mathrm{Cs}$ fluxes through the water column determined from accumulation rates in the traps. Whereas the top and mid-level collectors yielded comparable values, base-level collectors recorded significantly higher accumulation

Table 2 Mean ${ }^{210} \mathrm{~Pb}$ and ${ }^{137} \mathrm{Cs}$ concentrations in the water column sediment trap samples

\begin{tabular}{clllll}
\hline & ${ }^{210} \mathrm{~Pb}_{\text {uns }}$ & & & \multicolumn{2}{c}{${ }^{37} \mathrm{Cs}$} \\
\cline { 2 - 3 } \cline { 5 - 6 } Level & $\mathrm{Bq} \mathrm{kg}^{-1}$ & \pm & & $\mathrm{Bq} \mathrm{kg}^{-1}$ & \pm \\
\hline Trap A & & & & \\
Top & 369 & 10 & 47 & 2 \\
Mid & 342 & 10 & 49 & 2 \\
Base & 384 & 5 & 52 & 2 \\
Trap B & & & & 2 \\
Top & 566 & 10 & 65 & 2 \\
Mid & 446 & 12 & 55 & 2 \\
Base & 423 & 7 & 60 & 2 \\
\hline
\end{tabular}


rates. Given that the radionuclide fluxes are more or less in proportion to the sediment fluxes, the apparently higher fluxes in the base-level collectors are almost certainly due to resuspension of the bottom sediments. The similarity of the top and mid-level values suggests that resuspension here is not significant. Table 3 gives values of the water column fluxes at Trap A and Trap B obtained by combining results from the top and mid-level collectors for each collection period, and mean annual values based on total accumulations during the entire measurement period. The role of catchment inputs is evidenced by the fact that mean annual fluxes of both ${ }^{210} \mathrm{~Pb}$ and ${ }^{137} \mathrm{Cs}$ are significantly higher at Trap A (nearer to the inlet stream) than at the more distant Trap B. Further, the mean annual ${ }^{210} \mathrm{~Pb}$ fluxes $\left(316 \mathrm{~Bq} \mathrm{~m}^{-2}\right.$ year $^{-1}$ at Trap A, $278 \mathrm{~Bq} \mathrm{~m}^{-2}$ year $^{-1}$ at Trap B) are significantly higher than the estimated atmospheric flux $\left(183 \mathrm{~Bq} \mathrm{~m}^{-2}\right.$ year $\left.^{-1}\right)$. Since there has been no significant ${ }^{137}$ Cs fallout since 1986, catchment inputs can be the only source for this radionuclide.
These results also appear to show that ${ }^{210} \mathrm{~Pb}$ is more closely associated with fine sediments than ${ }^{137} \mathrm{Cs}$. Whereas ${ }^{137} \mathrm{Cs}$ concentrations on sediments from Trap $\mathrm{A}$ are twice as high as on sediments from the input stream, ${ }^{210} \mathrm{~Pb}$ concentrations are four times higher. This is further illustrated by the different relationships with sediment fluxes through the water column, shown in Fig. 3. ${ }^{210} \mathrm{~Pb}$ concentrations (Fig. 3a) show a strong inverse relationship, with high concentrations at times of low sediment flux and low concentrations at times of high sediment flux. Fine particulates are likely to be more dominant during periods of low flow. The possibility that this relationship might be due to dilution by algal production would appear to be precluded by the absence of any such relationship for ${ }^{137} \mathrm{Cs}$. In contrast to ${ }^{210} \mathrm{~Pb},{ }^{137} \mathrm{Cs}$ concentrations (Fig. 3b) have only a weak inverse relationship with the sedimentation rate.
Table 3 Sediment, ${ }^{210} \mathrm{~Pb}$ and ${ }^{137} \mathrm{Cs}$ fluxes through the water column of Brotherswater

\begin{tabular}{|c|c|c|c|c|}
\hline \multicolumn{5}{|c|}{ Water column fluxes } \\
\hline \multicolumn{2}{|c|}{ Measurement period } & \multirow{2}{*}{$\begin{array}{l}\text { Sediment } \\
\mathrm{g} \mathrm{cm}^{-2} \text { year }^{-1}\end{array}$} & \multirow{2}{*}{$\begin{array}{l}{ }^{210} \mathrm{~Pb}_{\text {uns }} \\
\mathrm{Bq} \mathrm{m}^{-2} \text { year }^{-1}\end{array}$} & \multirow{2}{*}{$\begin{array}{l}{ }^{137} \mathrm{Cs} \\
\mathrm{Bq} \mathrm{m}^{-2} \text { year }^{-1}\end{array}$} \\
\hline Start & Finish & & & \\
\hline \multicolumn{5}{|l|}{ Trap A } \\
\hline 15-Aug-12 & $10-$ Oct-12 & 0.152 & 367 & 71 \\
\hline $10-$ Oct- 12 & 09-Jan-13 & 0.115 & 348 & 61 \\
\hline 09-Jan-13 & $15-F e b-13$ & 0.154 & 483 & 84 \\
\hline $15-F e b-13$ & 24-Apr-13 & 0.059 & 299 & 38 \\
\hline 24-Apr-13 & 06-Jun-13 & 0.038 & 207 & 20 \\
\hline 06-Jun-13 & 10-Jul-13 & 0.023 & 105 & 13 \\
\hline 10-Jul-13 & 10-Aug-13 & 0.225 & 630 & 91 \\
\hline 10-Aug-13 & 10-Dec-13 & 0.057 & 246 & 25 \\
\hline Mean values & & 0.093 & 316 & 46 \\
\hline \multicolumn{5}{|l|}{ Trap B } \\
\hline 15-Aug-12 & $10-$ Oct-12 & 0.076 & 368 & 54 \\
\hline $10-$ Oct-12 & 09-Jan-13 & Sample lost & & \\
\hline 09-Jan-13 & $15-F e b-13$ & 0.061 & 260 & 41 \\
\hline $15-\mathrm{Feb}-13$ & 24-Apr-13 & 0.045 & 269 & 29 \\
\hline 24-Apr-13 & 06-Jun-13 & 0.033 & 193 & 20 \\
\hline 06-Jun-13 & 10-Jul-13 & 0.021 & 111 & 11 \\
\hline 10-Jul-13 & 10-Aug-13 & 0.119 & 558 & 63 \\
\hline 10-Aug-13 & 10-Dec-13 & 0.052 & 253 & 25 \\
\hline Mean values & & 0.056 & 278 & 33 \\
\hline
\end{tabular}



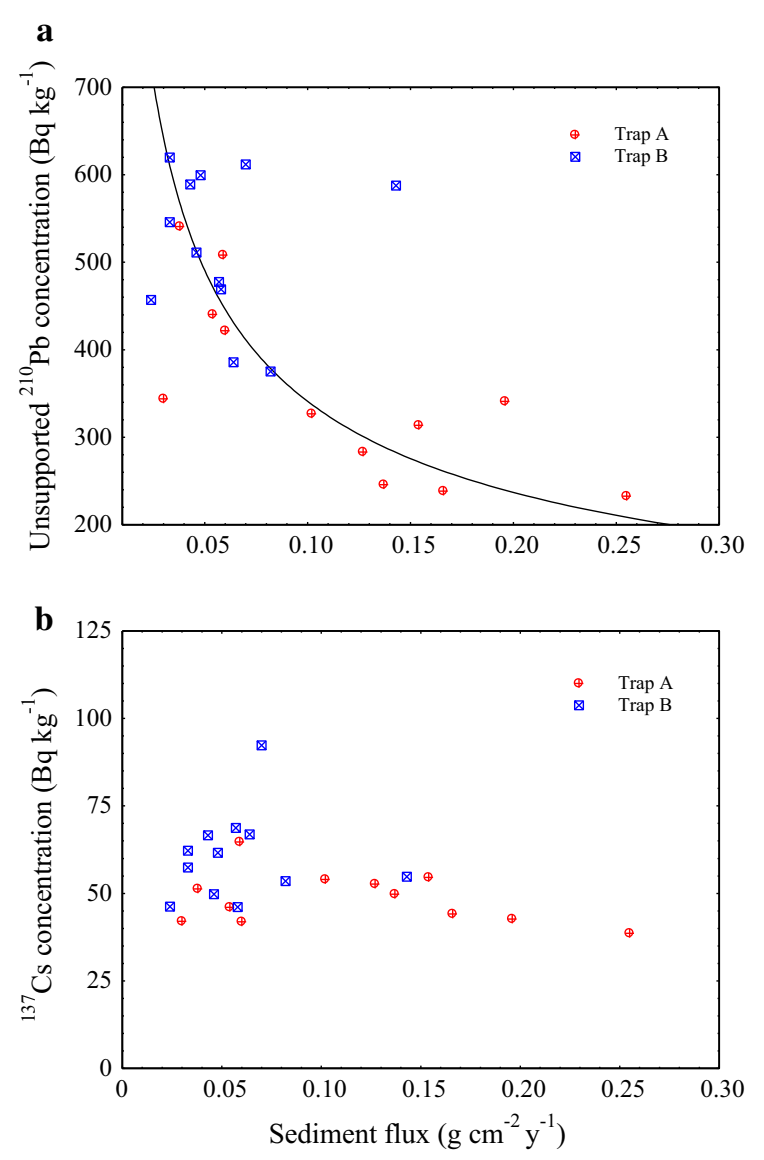

Fig. 3 Concentrations of $\mathbf{a}{ }^{210} \mathrm{~Pb}$ and $\mathbf{b}{ }^{137} \mathrm{Cs}$ in Brotherswater sediment trap samples versus sediment flux through the water column

Fallout ${ }^{210} \mathrm{P}$ and ${ }^{137} \mathrm{Cs}$ transport rates to the bottom sediments

ESM4 shows ${ }^{210} \mathrm{~Pb}$ and ${ }^{137} \mathrm{Cs}$ inventories in a total of 21 Brotherswater lake sediment cores including those from (a) the 1976/77 study, (b) the 1988/89 study and (c) during 2011/16. It also gives the mean ${ }^{210} \mathrm{~Pb}$ fluxes required to sustain the ${ }^{210} \mathrm{~Pb}$ inventories, determined by Eq. (1). Also shown are the ${ }^{137} \mathrm{Cs}$ inventories in two cores from the early 1970s (Pennington 1981; Semertzidou et al. 2019). Results for the pre-Chernobyl study include both the raw inventories and values decay corrected to 1986 . Those for the postChernobyl studies are all decay corrected to 1986, and also include estimates of the amounts attributable to fallout both from atmospheric nuclear weapons tests and from the 1986 Chernobyl accident. The relatively high mean value for the $1976 / 77{ }^{210} \mathrm{~Pb}$ inventories is due to anomalously high inventories in the BWE and BWN cores. The 1988/9 and 2011/16 cores have very similar mean values.

In order to carry out a mass balance calculation for ${ }^{210} \mathrm{~Pb}$ in Brotherswater it is necessary to determine the whole basin inventory and the mean supply rate needed to support it, or equivalently their mean values per unit area. The simplest way of doing this is from the arithmetical mean of the measured inventories or supply rates for a suite of cores providing a reasonable coverage of the entire bed of the lake. Since the atmospheric flux can be assumed relatively constant from year to year, such a calculation can include cores collected at different times. Applying this approach to all 21 sites listed in ESM4 the mean inventory is calculated to be $7664 \mathrm{~Bq} \mathrm{~m}^{-2}$. Alternatively, placing the sites into different groups by locality (Inlet, West, Central, South East, East, North), taking the mean of the group averages yielded a value of $7408 \mathrm{~Bq} \mathrm{~m}^{-2}$. A third calculation using weighted averages based on a grouping of the data into Voronoi cells (Fig. 4) gave values of between $8054 \mathrm{~Bq} \mathrm{~m}^{-2}$ when all the data were used and $7212 \mathrm{~Bq} \mathrm{~m}^{-2}$ when anomalous values from BWN and BWE were excluded. Using all four values, a best estimate of the mean inventory is 7584 $\pm 407 \mathrm{~Bq} \mathrm{~m}^{-2}$, giving a mean ${ }^{210} \mathrm{~Pb}$ supply rate to the sediment record of $236 \pm 13 \mathrm{~Bq} \mathrm{~m}^{-2}$ year $^{-1}$.

Estimates of the mean weapons test ${ }^{137} \mathrm{Cs}$ inventory (decay corrected to 1986) suggest that it has remained relatively stable, increasing slightly from just over $5000 \mathrm{~Bq} \mathrm{~m}^{-2}$ in the 1970 s and 1980 s to a contemporary value of $5381 \mathrm{~Bq} \mathrm{~m}^{-2}$. The Chernobyl inventory appears to have increased from $649 \mathrm{~Bq} \mathrm{~m}^{-2}$ to a contemporary value of $1084 \mathrm{~Bq} \mathrm{~m}^{-2}$. These values reflect inputs by direct fallout and catchment transport less losses via the outflow.

\section{Discussion}

The fate of any chemical species entering the water column of a lake will be largely determined by its distribution between the particulate, colloidal and soluble phases. The soluble fraction and fraction attached to colloidal size particle $(<0.4 \mu \mathrm{m})$ are essentially transported with the aqueous phase. The fate of the particulate fraction, and in particular the extent to which it is deposited on the bed of the lake or lost via the outflow, is largely determined by factors 

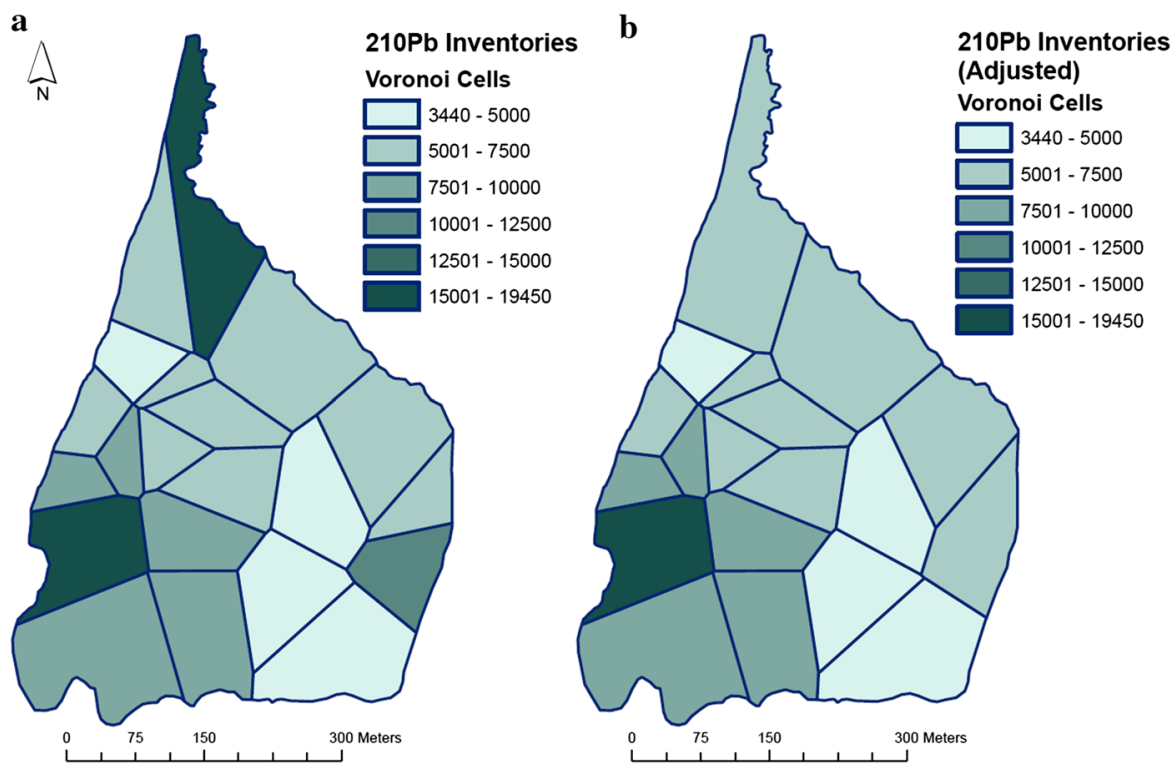

Fig. 4 Voronoi diagrams for ${ }^{210} \mathrm{~Pb}$ inventories $\left(\mathrm{Bq} \mathrm{m}^{-2}\right.$ year $\left.{ }^{-1}\right)$ in Brotherswater sediments $\mathbf{a}$ using all the data and $\mathbf{b}$ excluding the anomalous values from BWN and BW

controlling the transport of suspended sediments through the lake. These include the particle-size distribution, water depth, and water residence time. Since the main unknowns concerning the source of radionuclides to the sediment record are catchment inputs and outflow losses we begin with a brief discussion of water balance and sediment transport in Brotherswater.

\section{Water balance}

Chambers (1978) carried out weekly measurements of the discharge through streams flowing into and out of Brotherswater over a 2-year period from 25th September 1975 to 25th September 1977. Estimates of the mean annual discharge rates based on a simple numerical procedure for integrating the individual measurements yielded values of $24.75 \times 10^{6} \mathrm{~m}^{3}$ year ${ }^{-1}$ and $28.35 \times 10^{6} \mathrm{~m}^{3}$ year $^{-1}$ for the mean inflow rate and outflow rates respectively. The difference between the two can be attributed to additional inputs via direct rainfall onto the lake $\left(0.47 \times 10^{6} \mathrm{~m}^{3}\right.$ year $\left.{ }^{-1}\right)$ and groundwater flow $\left(3.13 \times 10^{6} \mathrm{~m}^{3}\right.$ year $\left.^{-1}\right)$. The calculations necessarily underestimated the impact of flood events that took place between flow measurements. Although it was estimated that these might have accounted for an additional inflow of
$19.05 \times 10^{6} \mathrm{~m}^{3}$ year $^{-1}$, the procedure was acknowledged by Chambers to be highly uncertain and give no better than an order of magnitude of the true figure. Daily precipitation data from the nearby Grisedale Bridge monitoring station (Met Office 2006) indicate that $36 \%$ of rainfall during the period monitored by Chambers fell on days with $25 \mathrm{~mm}$ of rain or more.

Water balance calculations based on the rainfall estimate (2609 $\mathrm{mm} \mathrm{year}^{-1}$ ) suggest an upper limit for the mean annual stream inflow of $30.8 \times 10^{6} \mathrm{~m}^{3}$ year $^{-1}$. The discrepancy with Chambers' estimate may in part be due to higher rainfall in the high-altitude parts of the catchment. Table 4 gives estimated values of water inputs and outputs for Brotherswater based on Chambers results but using an intermediate value for inputs during flood conditions. The results are reasonably consistent with the Grisedale data in that they imply that flood conditions account for $34 \%$ of total stream inputs. From the total discharge $\left(40.9 \times 10^{6} \mathrm{~m}^{3}\right.$ year $\left.^{-1}\right)$ and lake volume $\left(1.33 \times 10^{6} \mathrm{~m}^{3}\right.$, Schillereff et al. 2019) the mean water residence time for Brotherswater is calculated to be 12 days. Other estimates in the literature vary from 7 days (Eakins et al. 1984) to 21 days (Maberly et al. 2011). This range of values may in part reflect the fact that the residence time will be considerably less than 12 days during flood events and considerably longer during periods of low flow. 
Table 4 Water balance estimates for Brotherswater

\begin{tabular}{llc}
\hline Inputs & & $10^{6} \mathrm{~m}^{3} \mathrm{year}^{-1}$ \\
Input stream & Normal flow & 24.75 \\
& Flood conditions & 12.55 \\
& Total & 37.30 \\
Direct rainfall onto the lake & & 0.47 \\
Groundwater flow & & 3.13 \\
& Total inputs & 40.90 \\
Outputs & & \\
Outlet stream & Normal flow & 28.35 \\
& Flood conditions & 12.55 \\
& Total outputs & 40.90 \\
\hline
\end{tabular}

\section{Sediment transport}

The input of suspended sediments, the main vector for transporting fallout ${ }^{210} \mathrm{~Pb}$ through the water column of a lake, were also monitored weekly by Chambers over a period of about 1 year, from 11 October 1976 to 25 November 1977. The calculated load based on these measurements, $81 \times 10^{3} \mathrm{~kg} \mathrm{year}^{-1}$, was however thought to greatly underestimate the total load. Particle concentrations were found to be up to three orders of magnitude higher during flood events, most of which were not picked up by the weekly monitoring.

The extent to which sediments entering the water column of Brotherswater accumulate in the sediment record can be determined using ${ }^{210} \mathrm{~Pb}$ records from the suite of cores collected during this and earlier studies, shown in Fig. 1. Sedimentation rates determined from the ${ }^{210} \mathrm{~Pb}$ records were consistent with chronostratigraphic dates determined from the ${ }^{137} \mathrm{Cs}$ records (Semertzidou et al. 2019). A good estimate of the mean long-term accumulation rate at any individual site is given by the $90 \%{ }^{210} \mathrm{~Pb}$ equilibrium depth, corresponding to 75 years accumulation. Mean sedimentation rates determined in this way ranged from $0.173 \mathrm{~g} \mathrm{~cm}^{-2}$ year $^{-1}$ at BW11/2 (relatively near the mouth of the main inlet stream) to $0.026 \mathrm{~g} \mathrm{~cm}^{-2}$ year $^{-1}$ at BW16/SE2 (towards the south-eastern corner of the lake) and are consistent with the sediment trap data which suggest sediment fluxes through the water column of $0.093 \mathrm{~g} \mathrm{~cm}^{-2}$ year $^{-1}$ at Site A near the inflow stream and $0.056 \mathrm{~g} \mathrm{~cm}^{-2}$ year $^{-1}$ at Site B near the centre of the lake. Integrating over all the data, the mean accumulation rate was calculated to be
$0.059 \mathrm{~g} \mathrm{~cm}^{-2}$ year $^{-1}$ giving a mean whole basin accumulation rate of $106 \times 10^{3} \mathrm{~kg}_{\text {year }}{ }^{-1}$.

Because of the buffering effect of the lake, particle concentrations at the outflow will be much more uniform than at the inflow. Suspended sediment concentrations in samples collected from the outflow during weekly monitoring (Eakins et al. 1981, 1984) had a mean value of $1.1 \mathrm{mg} \mathrm{L}^{-1}$. Assuming this to be typical of the total discharge through the outflow $\left(40.9 \times 10^{6} \mathrm{~m}^{3}\right.$ year $\left.^{-1}\right)$, the total sediment loss via the outflow is calculated to be $46 \times 10^{3} \mathrm{~kg}_{\text {year }}{ }^{-1}$. The combined total $\left(152 \times 10^{3} \mathrm{~kg}\right.$ year $\left.^{-1}\right)$ of losses via sedimentation and outflow is nearly double Chambers measured value of inputs during normal flow conditions $\left(81 \times 10^{3} \mathrm{~kg}\right.$ year $\left.^{-1}\right)$ and probably a good measure of the total input of relatively fine sediments from the catchment. The higher figure $\left(\approx 1300 \times 10^{3} \mathrm{~kg} \mathrm{year}^{-1}\right)$ suggested by Chambers when flood events are included, if correct would almost certainly be mainly due to inputs of relatively coarse material (sand and gravel) mobilised during flood events and deposited in a delta relatively close to the point of entry to the lake. That such material is unlikely to contribute significantly to catchment inputs of ${ }^{210} \mathrm{~Pb}$ is supported by results from a recent (2017) core collected from the delta. The mean ${ }^{210} \mathrm{~Pb}$ supply rate to this core $\left(251 \mathrm{~Bq} \mathrm{~m}^{-2}\right.$ year $\left.^{-1}\right)$ was just $6 \%$ higher than the whole lake mean.

${ }^{210} \mathrm{~Pb}$ mass balance

From the estimated values of the atmospheric flux (183 $\mathrm{Bq} \mathrm{m}^{-2}$ year ${ }^{-1}$ ) and mean ${ }^{210} \mathrm{~Pb}$ supply rate to the sediment record $\left(236 \mathrm{~Bq} \mathrm{~m}^{-2}\right.$ year $\left.^{-1}\right)$ the total amounts of ${ }^{210} \mathrm{~Pb}$ entering the water column of 
Brotherswater via direct fallout onto its surface and exiting via deposition over the bed of the lake are calculated to be $3.30 \times 10^{7} \mathrm{~Bq} \mathrm{year}^{-1}$ and $4.26 \times 10^{7} \mathrm{~Bq} \mathrm{year}^{-1}$ respectively. The difference between these figures, $0.96 \times 10^{7} \mathrm{~Bq} \mathrm{year}^{-1}$ is a measure of the extent to which inputs from the catchment exceed losses via the outflow. In the study carried out by Eakins et al. it was assumed that ${ }^{210} \mathrm{~Pb}$ concentrations on all sediments entering the lake (including those during storm events) were similar to those on suspended sediments in the water column, estimated to be $10.3 \mathrm{pCi} \mathrm{g}^{-1}\left(381 \mathrm{~Bq} \mathrm{~kg}^{-1}\right)$. Measurements carried out during the present study suggest a much lower figure, particularly during flood events. Unsupported ${ }^{210} \mathrm{~Pb}$ concentrations (Table 1) varied widely from as little as $13 \mathrm{~Bq} \mathrm{~kg}^{-1}$ to more than $200 \mathrm{~Bq} \mathrm{~kg}{ }^{-1}$. Sediments transported during flood events include large quantities of relatively coarse material containing relatively little ${ }^{210} \mathrm{~Pb}$, exemplified by the October 2016b and October 2017b samples. Excluding these, the mean unsupported ${ }^{210} \mathrm{~Pb}$ concentration on the remaining mainly fine-grained material was around $109 \mathrm{~Bq} \mathrm{~kg}^{-1}$. Assuming this to be typical of the estimated $152 \times 10^{3} \mathrm{~kg}_{\text {year }}{ }^{-1}$ of fine sediments entering the lake via the main inflow, and again supposing that $25 \%$ of ${ }^{210} \mathrm{~Pb}$ was on colloidal material and effectively in solution, the contribution of this material to the amount of catchment derived ${ }^{210} \mathrm{~Pb}$ entering the lake is calculated to be $2.21 \times 10^{7} \mathrm{~Bq} \mathrm{y}^{-1}$. Assuming further that the coarse sediments transported during flood events (up to $1200 \times 10^{3} \mathrm{~kg}$ year $^{-1}$ according to Chambers' estimates) had a minimal unsupported ${ }^{210} \mathrm{~Pb}$ concentration of $15 \mathrm{~Bq} \mathrm{~kg}^{-1}$ (the mean value of the October $b$ samples), total inputs of catchment derived ${ }^{210} \mathrm{~Pb}$ are calculated to be $4.70 \times 10^{7} \mathrm{~Bq}_{\text {year }}{ }^{-1}$. An alternative estimate can be made using the measurements carried out by Eakins et al. $(1981,1984)$ on water samples from the Brotherswater inlet stream. Concentrations on samples collected on five occasions during July 1976 to November 1977 under both low flow conditions and following heavy rain ranged from 0.5 to $2.6 \mathrm{~Bq} \mathrm{~kL}^{-1}$ (14-70 $\mathrm{fCi} \mathrm{L}^{-1}$ ) with a mean value of $1.5 \mathrm{~Bq} \mathrm{~kL}^{-1}$ (41 $\mathrm{fCi} \mathrm{L}^{-1}$ ). Multiplying by the estimated discharge rate through the inflow of $37.3 \times 10^{6} \mathrm{~m}^{3}$ year $^{-1}$, this calculation suggests an annual rate of supply of ${ }^{210} \mathrm{~Pb}$ from the catchment of $5.69 \times 10^{7} \mathrm{~Bq} \mathrm{year}^{-1}$. The average of these two estimates $\left(5.19 \times 10^{7} \mathrm{~Bq} \mathrm{year}^{-1}\right)$ puts the value for total mean annual inputs of ${ }^{210} \mathrm{~Pb}$ to the water column at $8.49 \times 10^{7} \mathrm{~Bq} \mathrm{year}^{-1}$.

Eakins et al. (1981, 1984) carried out measurements of ${ }^{210} \mathrm{~Pb}$ in water samples collected from the Brotherswater outflow stream on five occasions during July 1976 to November 1977 under both low flow conditions and following heavy rain. Concentrations ranged from 0.9 to $3.2 \mathrm{~Bq} \mathrm{~kL}^{-1}\left(23-87 \mathrm{fCi} \mathrm{L}^{-1}\right.$ ) with a mean value of $1.8 \mathrm{~Bq} \mathrm{~kL}^{-1}$ ( $49 \mathrm{fCi} \mathrm{L}^{-1}$ ). Multiplying by the estimated mean outflow rate $\left(40.9 \times 10^{6} \mathrm{~m}^{3}\right.$ year ${ }^{-1}$ ), one estimate of the annual rate of loss of ${ }^{210} \mathrm{~Pb}$ from the lake via the outflow is calculated to be $7.36 \times 10^{7} \mathrm{~Bq} \mathrm{year}^{-1}$. Because of the relative sparsity of the measurements and their wide range of values this figure does however have a large uncertainty. An alternative estimate can be made using measured values of the ${ }^{210} \mathrm{~Pb}$ concentrations on suspended particulates in the water column. Unsupported ${ }^{210} \mathrm{~Pb}$ concentrations on samples from sediment Trap B near the centre of the lake were significantly higher than those in samples from Trap A, closer to the inflow, presumably due to the progressive settling out of coarser particles with lower concentrations. Mean concentrations in Trap B samples (Table 2) ranged from $423 \mathrm{~Bq} \mathrm{~kg}^{-1}$ in the base-level collector to $566 \mathrm{~Bq} \mathrm{~kg}^{-1}$ in the top-level collector. Assuming the latter value to be more typical of suspended sediments reaching the outflow, multiplying by the estimated sediment load $\left(46 \times 10^{3} \mathrm{~kg} \mathrm{year}^{-1}\right)$, and also allowing for the estimated $25 \%$ of ${ }^{210} \mathrm{~Pb}$ on fine material that is essentially transported with the aqueous phase (Eakins et al. 1981, 1984), this method gives a lower value of $3.44 \times 10^{7} \mathrm{~Bq}_{\text {year }}{ }^{-1}$ for the ${ }^{210} \mathrm{~Pb}$ outflow rate. From the mean value $\left(5.40 \times 10^{7}\right.$ Bq year ${ }^{-1}$ ) total mean annual losses of ${ }^{210} \mathrm{~Pb}$ from the water column are put at $9.66 \times 10^{7} \mathrm{~Bq} \mathrm{year}^{-1}$. The discrepancy between this figure and the above estimate for total inputs to the water column (an imbalance of $1.17 \times 10^{7} \mathrm{~Bq}_{\text {year }}{ }^{-1}$ ) is mainly due to uncertainties in the values of the catchment inputs and outflow losses. Making proportionate corrections to these terms gives a corrected figure of $9.06 \times 10^{7} \mathrm{~Bq} \mathrm{y}^{-1}$ for total inputs to and losses from the water column. It follows from this that catchment inputs must be around $5.76 \times 10^{7} \mathrm{~Bq}_{\text {year }}{ }^{-1}$ and outflow losses $4.80 \times 10^{7} \mathrm{~Bq}_{\text {year }}{ }^{-1}$. The mass balance requirements coupled with relatively low uncertainties in the atmospheric flux $(\sim 3 \%)$ and supply rate to the sediments $(\sim 6 \%)$ place a relatively strong 


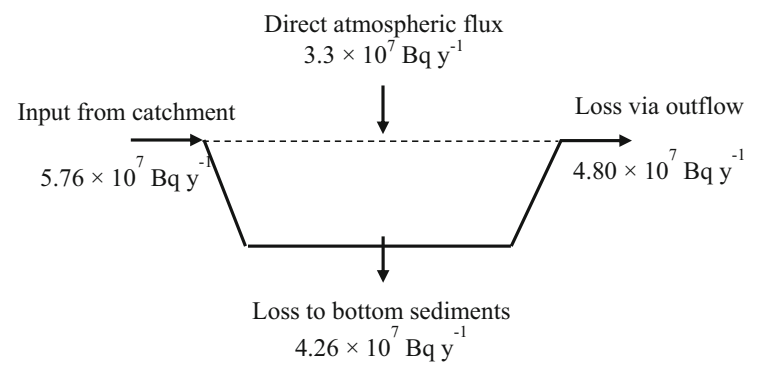

Fig. 5 Mass balance for ${ }^{210} \mathrm{~Pb}$ in Brotherswater

constraint on the apparently large uncertainties in these values. Assuming them to be comparable, since their difference has an uncertainty of around $0.25 \times 10^{7} \mathrm{~Bq} \mathrm{year}^{-1}$, they are each likely to have an uncertainty of around $8 \%$.

The final result, shown in Fig. 5, suggests that transport from the catchment accounts for $64 \%$ of ${ }^{210} \mathrm{~Pb}$ entering the water column of Brotherswater. In comparison, in a similar study carried out at Blelham Tarn, with a smaller but still relatively large catchment/lake area ratio (42 compared to 72 at Brotherswater), indirect inputs of ${ }^{210} \mathrm{~Pb}$ via the catchment were shown to account for a smaller proportion (47\%) of total inputs (Appleby et al. 2003). The much lower fraction $(25 \%)$ lost via the outflow at Blelham Tarn can at least in part be attributed to its longer water residence time (32 days compared to 12 days at Brotherswater).

Mean particle size for sediments transporting ${ }^{210} \mathrm{~Pb}$

The relatively high fraction of ${ }^{210} \mathrm{~Pb}$ lost via the outflow (53\%) is surprising, given that particle size analyses carried out on sediment trap samples (Schillereff et al. 2016a) showed a substantial fraction in excess of $10 \mu \mathrm{m}$. The fate ${ }^{210} \mathrm{~Pb}$ entering the waster column is controlled by factors such as the water residence time $T_{W}$, the fraction of ${ }^{210} \mathrm{~Pb}$ in the water column attached to particulates $f_{D}$, the settling velocity of the particulates $v$, and the mean water depth $d$. From Stoke's law the settling velocity for particles of diameter $D \mu \mathrm{m}$ can be written

$v=0.058 D^{2} \mathrm{~m} \mathrm{~d}^{-1}$

Following Appleby (1997), the fraction of ${ }^{210} \mathrm{~Pb}$ inputs transferred to the sediment record is given by the equation
$\mathcal{F}_{P b}=\frac{f_{D} T_{L}}{T_{S}}$,

where $T_{S}=d / v$ is the settling time and $T_{L}$ the ${ }^{210} \mathrm{~Pb}$ residence time, given by

$\frac{1}{T_{L}}=\frac{f_{D}}{T_{S}}+\frac{1}{T_{W}}$.

Substituting into the expression for the particle settling time $T_{S}$, the expression for the retention fraction can be rearranged to give an explicit relation

$\mathcal{F}_{P b}=\frac{1}{1+\frac{d}{0.058 D^{2} f_{D} T_{W}}}$

between the retention fraction and particle size. Assuming a mean water depth in Brotherswater of $7.4 \mathrm{~m}$ and mean water residence time of 12 days, Fig. 6 plots values of $\mathcal{F}_{P b}$ against particle diameter for values of the particulate fraction $f_{D}$ in the range $0.75-$ 0.85 . The results show that the value of $\mathcal{F}_{P b}$ is relative insensitive to the precise value of $f_{D}$ but strongly dependent on particle size. The fraction of ${ }^{210} \mathrm{~Pb}$ transported to the sediment record is less than $10 \%$ for particles less than $1 \mu \mathrm{m}$ and over $90 \%$ for particle larger than $10 \mu \mathrm{m}$. For particles between 2 and $6 \mu \mathrm{m}$, it increases rapidly from around $25 \%$ to $75 \%$. Since the empirically determined value of $\mathcal{F}_{P b}$ is 0.47 , it appears that the bulk of ${ }^{210} \mathrm{~Pb}$ in the water column of Brotherswater is transported on particulates with a mean size of around 3-4 $\mathrm{m}$. The particle size

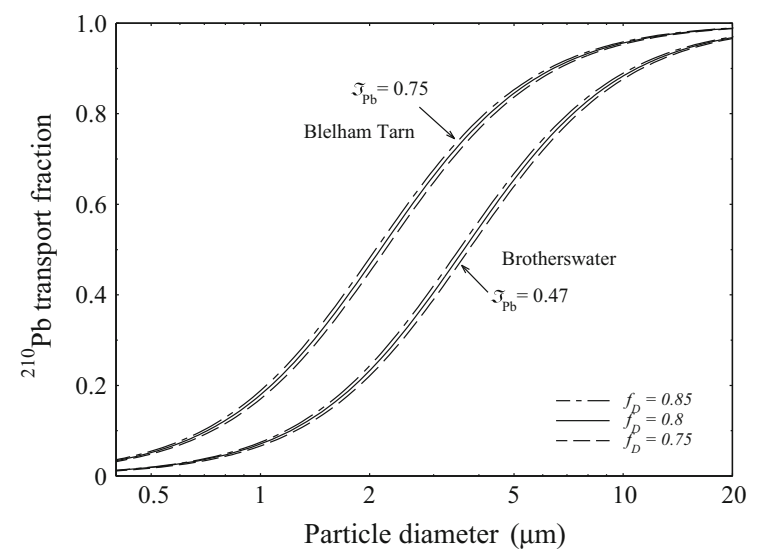

Fig. 6 Modelled values of the ${ }^{210} \mathrm{~Pb}$ sediment record transfer fractions in Brotherswater and Blelham Tarn versus particle size. The empirically determined values suggests that at both sites ${ }^{210} \mathrm{~Pb}$ is mainly transported on particulates with a mean size of around 3-4 $\mu \mathrm{m}$ 


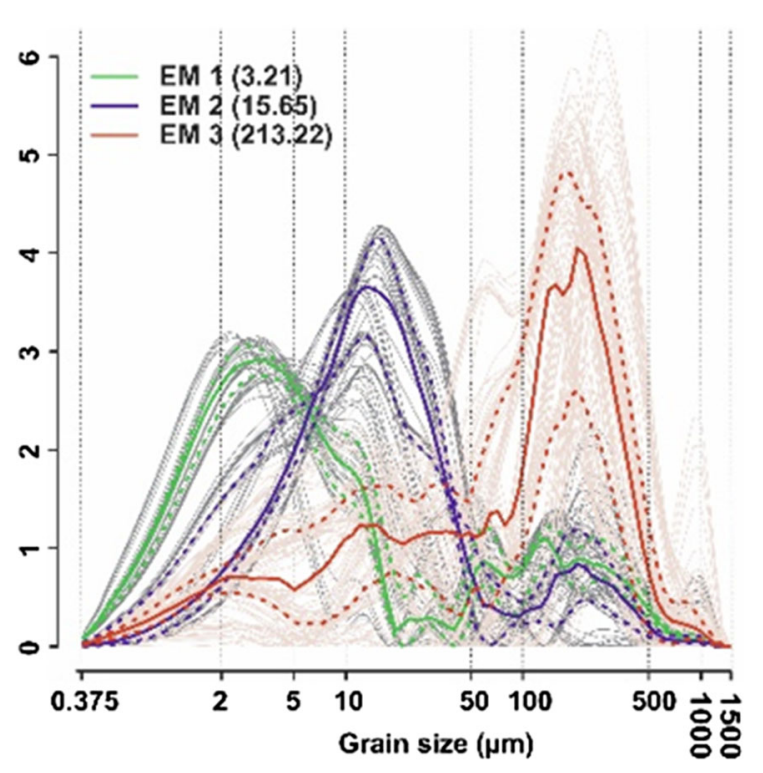

Fig. 7 Particle size distributions for sediment trap and core samples from Brotherswater (modified from Schillereff et al. 2019)

analyses carried out by Schillereff et al. (2019) revealed the presence of three members (Fig. 7), EM1 (mean particle size $3.21 \mu \mathrm{m})$, EM2 $(15.65 \mu \mathrm{m})$ and EM3 $(213.22 \mu \mathrm{m})$. The member EM1 was attributed to soil weathering and erosion, and EM2 to eroded streambank material. The results shown here, that ${ }^{210} \mathrm{~Pb}$ is transported mainly on particles within EM1, is consistent with the fact that whereas eroded streambanks are unlikely to include significant amounts of fallout ${ }^{210} \mathrm{~Pb}$, surface soils are likely to have high concentrations.

Figure 6 also plots corresponding values of the sediment transfer fraction for Blelham Tarn determined from the relevant lake data for that site. The empirically determined value of 0.75 suggests that there too ${ }^{210} \mathrm{~Pb}$ is mainly transported on particulates with a mean size of around 3-4 $\mu \mathrm{m}$.

\section{Catchment/lake transport parameters}

The above results illustrate the extent to which catchment inputs may be a significant source of ${ }^{210} \mathrm{~Pb}$ in lakes with large catchment/lake area ratios. Writing $\eta_{P b}$ for the amount delivered to the lake as a fraction of annual fallout onto the catchment the catchment/lake transport rate can be written
$\Psi_{C}(t)=A_{L} \alpha \eta_{P b} P$,

where $\mathrm{P}$ is the atmospheric flux, $A_{L}$ the area of the lake, and $\alpha$ the catchment/lake area ratio. Substituting the values $\mathrm{P}=183 \mathrm{~Bq} \mathrm{~m}^{-2}$ year $^{-1}, \quad A_{L}=0.18 \mathrm{~km}^{2}$, $\alpha=72, \quad \Psi_{\mathrm{C}}=5.76 \times 10^{7} \mathrm{~Bq}$ year $^{-1}$ the transport parameter $\eta_{P b}$ is calculated to be 0.024 . Thus although around $63 \%$ of ${ }^{210} \mathrm{~Pb}$ entering the water column of Brotherswater (Fig. 5) is catchment derived, this represents just $2.4 \%$ of annual fallout onto the catchment. Using the catchment/lake transport model outlined in Appleby et al. (2003) we assume a unit response function of the form

$$
\mathrm{h}(s)=\frac{k}{\sqrt{s}} \mathrm{e}^{-2 k \sqrt{s}},
$$

where $\mathrm{h}(s)$ is the transport rate $s$ years later due to initial deposition of a unit of fallout on the catchment. In the case of ${ }^{210} \mathrm{~Pb}$ the transport parameter is related to the transport coefficient $k$ by

$\eta_{P b}=\int_{0}^{\infty} \frac{k}{\sqrt{s}} \mathrm{e}^{-(\lambda s+2 k \sqrt{s})} d s$.

Solving, the transport coefficient $k$ is calculated to be 0.0024 year $^{-0.5}$. The corresponding value for Blelham Tarn was 0.0022 year $^{-0.5}$ (Appleby et al. 2003). In principle this parameter can be used to estimate catchment/transport rates for any atmospherically delivered contaminant with geochemical properties similar to that of ${ }^{210} \mathrm{~Pb}$, including stable $\mathrm{Pb}$.

${ }^{137} \mathrm{Cs}$ mass balance and transport

Inputs of ${ }^{137}$ Cs to Brotherswater

Whereas ${ }^{210} \mathrm{~Pb}$ fallout is relatively constant from year to year, ${ }^{137} \mathrm{Cs}$ deposition was much more episodic. Global fallout from the atmospheric testing of nuclear weapons began with the onset of thermo-nuclear testing in 1953/4, reaching a peak in 1963. Fallout fell sharply following the 1963 treaty banning atmospheric testing and to levels below limits of detection by the end of 1985. Fallout from the 1986 Chernobyl nuclear reactor fire occurred within the space of no more than a few days. From the historical record (Cambray et al. 1989), the cumulative weapons test fallout at Brotherswater decay corrected to $1986\left(7610 \mathrm{~Bq} \mathrm{~m}^{-2}\right)$ corresponds to a nominal atmospheric flux (defined as the sum of all the annual fallout amounts) of 
$12,700 \mathrm{~Bq} \mathrm{~m}^{-2}$. Mutiplying the atmospheric flux by the area of the lake, direct inputs to the lake from weapons test fallout are estimated to have totalled $2.29 \times 10^{6} \mathrm{kBq}$ (or $1.37 \times 10^{6} \mathrm{kBq}$ decay corrected to 1986). Inputs for any given year can be calculated by multiplying the nominal total by the fraction of the total that fell in that year. The Chernobyl fallout will have contributed a further $0.72 \times 10^{6} \mathrm{kBq}$. Direct inputs from both sources are shown in Fig. 8 .

Indirect inputs arising from fallout onto to the catchment will however have made a continuing contribution through to the present day. Because of its larger area, weapons test fallout is estimated to have deposited $165 \times 10^{6} \mathrm{kBq}$ (or $99 \times 10^{6} \mathrm{kBq}$ decay corrected to 1986) on the catchment. Fallout for any given year can be calculated by a corresponding scaling of the historical record. Chernobyl fallout will have contributed a further $52 \times 10^{6} \mathrm{kBq}$. Catchment/ lake transport rates arising from fallout in a given year will have been relatively high immediately following deposition but significantly lower in later years as ${ }^{137} \mathrm{Cs}$ diffuses deeper into the catchment soils and becomes less available for removal. In modelling this we again follow Appleby et al. (2003) in supposing that the transport rate due to a unit amount of fallout on the catchment in a particular year can be characterised by a unit response function $\mathrm{h}(s)$ (Eq. 8) where $k$ is in this case a transport coefficient for ${ }^{137} \mathrm{Cs}$. Writing $Q(t)$ for the nominal fallout in year $t$ (where $t$ takes values from 1954 through to 1985), the amount transported to the lake during the sth year following year $t$ will be

$$
\begin{aligned}
& Q(t) \mathrm{e}^{-\lambda s} \int_{s-1}^{s} \frac{k}{\sqrt{u}} \mathrm{e}^{-2 k \sqrt{u}} d u \\
& \quad=Q(t) \mathrm{e}^{-\lambda s}\left(\mathrm{e}^{-2 k \sqrt{s-1}}-\mathrm{e}^{-2 k \sqrt{s}}\right)
\end{aligned}
$$

(where the dummy parameter $u$ again represents time). The total input of ${ }^{137} \mathrm{Cs}$ from the catchment in year $t$ can be calculated by summing contributions in that year from fallout in all years $t^{\prime}<t$. Measurements of (weapons test) ${ }^{137}$ Cs concentrations in water samples collected by Eakins et al. $(1981,1984)$ on three occasions during July 1976 to May 1977 from the Brotherswater inlet stream, under both low flow conditions and following heavy rain, ranged from 0.9 to $5.6 \mathrm{~Bq} \mathrm{~kL}^{-1}$. Concentrations in a further 6 samples collected from the lower reaches of the Kirkstone and Caiston becks were in a similar range. The mean value from all the measurements was $3.9 \mathrm{~Bq} \mathrm{~kL}^{-1}$. Multiplying by the estimated discharge rate through the inflow $\left(37.3 \times 10^{6} \mathrm{~m}^{3} \mathrm{y}^{-1}\right)$, this calculation suggests an annual rate of transport of ${ }^{137} \mathrm{Cs}$ from the catchment at that time (14 years after 1963 ) of $14.6 \times 10^{7} \mathrm{~Bq} \mathrm{year}^{-1}$. Matching the measured value to the modelled value for 1976/77 the value of $k$ is calculated to be 0.0046 year $^{-0.5}$.
Fig. 8 Inputs of ${ }^{137} \mathrm{Cs}$ to Brotherswater including direct fallout, transport from the catchment, and total inputs

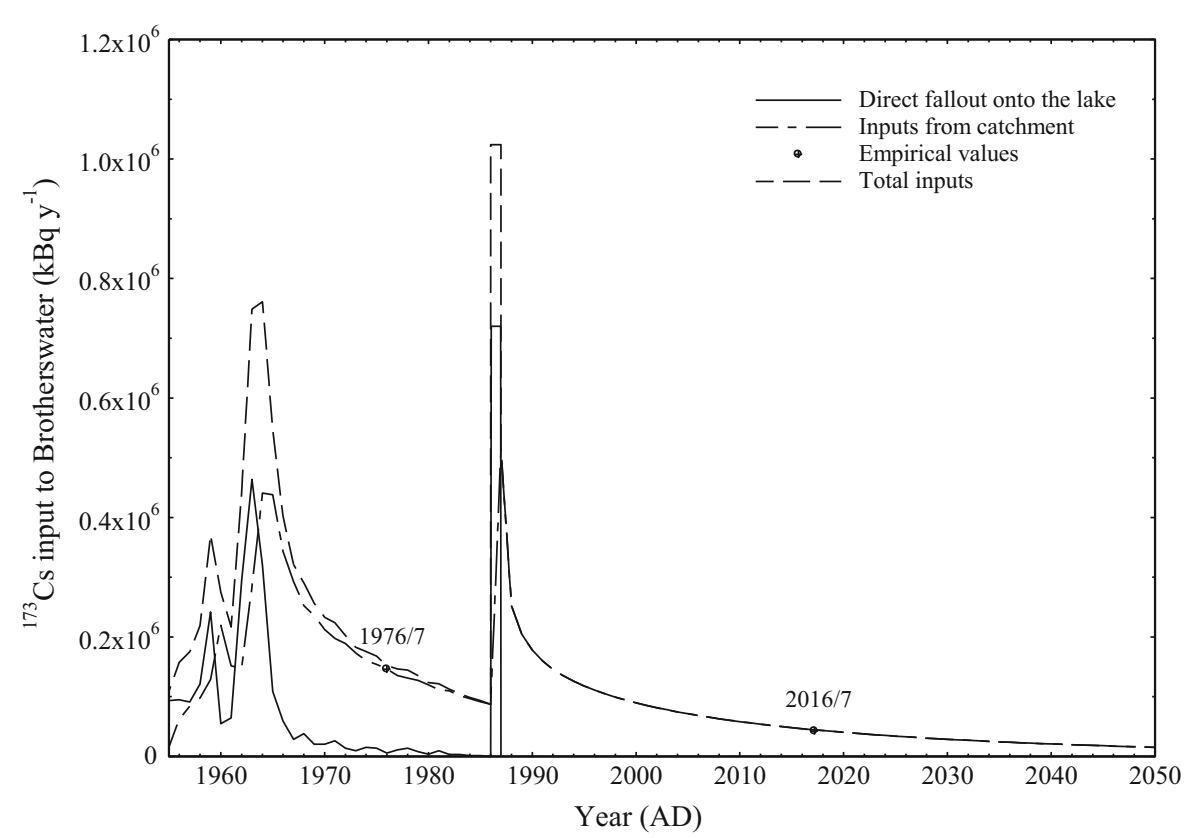


${ }^{137} \mathrm{Cs}$ concentrations on sediment samples from traps placed in the main Brotherswater inflow stream during the period from July 2016 through to October 2017 (Table 1) varied from $12 \mathrm{~Bq} \mathrm{~kg}^{-1}$ to $42 \mathrm{~Bq} \mathrm{~kg}^{-1}$. Excluding the relatively coarse material transported during flood events (October 2016b and October 2017b) the mean ${ }^{137} \mathrm{Cs}$ concentration on the remaining mainly fine-grained material was around $30 \mathrm{~Bq} \mathrm{~kg}^{-1}$. Assuming this to be typical of the estimated $152 \times 10^{3} \mathrm{~kg}$ year $^{-1}$ of fine sediments entering the lake via the main inflow, and that concentrations on the October 2016b and October $2017 \mathrm{~b}$ samples $\left(12 \mathrm{~Bq} \mathrm{~kg}^{-1}\right)$ are typical of coarse sediments, inputs of ${ }^{137} \mathrm{Cs}$ on suspended sediments entering the lake during this period are estimated to be $1.94 \times 10^{7} \mathrm{~Bq}_{\text {year }}{ }^{-1}$. Total inputs will however also include a substantial fraction present in the essentially aqueous $(<0.45 \mu \mathrm{m})$ phase. Measurements of ${ }^{137} \mathrm{Cs}$ concentrations in lake waters (Liverpool University ERRC data base) yielded values of the particulate fraction $f_{D}$ ranging from as little as $11 \%$ to as much as $40 \%$, with a mean value of around $25 \%$. Results from river waters suggest significantly higher values. Measurements carried out at five sites in the Dnieper river system between 1987 and 1993 (Sansone et al. 1996) yielded mean values of $f_{D}$ ranging from 26 to $34 \%$ with a mean value of $30 \%$. During that period values of the particulate fraction remained relatively constant in spite of an $80 \%$ decline in concentrations. Results from a number of rivers in Belarus, Austria, Lithunia (Monte et al. 2002), although more varied had a similar mean value (34\%). Since the main driver for higher ${ }^{137} \mathrm{Cs}$ concentrations during flood events will be higher concentrations of suspended sediments remobilised from the bed of the stream or eroded from catchment soils adjacent to the stream, concentrations in the essentially aqueous phase are likely to be comparable to those during normal flow. Assuming a value of $30 \%$ for the particulate fraction $f_{D}$ during normal flow, inputs of ${ }^{137} \mathrm{Cs}$ aqueous inputs by 2017 are estimated to be $2.32 \times 10^{7} \mathrm{~Bq} \mathrm{year}^{-1}$, and total inputs $4.26 \times 10^{7} \mathrm{~Bq} \mathrm{year}^{-1}$. Matching this empirical value to the modelled value for the beginning of 2017 gives a slightly lower value for $k$ of 0.0039 year $^{-0.5}$. Using the mean value 0.0043 year $^{-0.5}$ as a best value for $k$, Fig. 8 also shows modelled values of catchment inputs of ${ }^{137} \mathrm{Cs}$ to Brotherswater from 1954 through to 2050 and compares them with the empirical values for 1976/77 and 2016/17. The results suggest that inputs of weapons fallout from the catchment peaked slightly later than direct inputs, and at their peak were comparable to direct inputs. From the late 1960s onwards catchment inputs were the dominant source of ${ }^{137}$ Cs entering Brotherswater, apart from 1986 when there was a brief but intense episode of fallout from the Chernobyl accident. The impact of catchment inputs when added to direct inputs was to significantly broaden the early 1960 s peak delivery of ${ }^{137} \mathrm{Cs}$ to Brotherswater (Fig. 8).

\section{Transport of ${ }^{137}$ Cs through the water column}

${ }^{137} \mathrm{Cs}$ entering Brotherswater has a relatively short residence time in the water column and will exit it either by transport to the bed of the lake on sedimenting particles or by passage through the outflow. The sediment trap results and sediment cores both suggest that the bulk of it is lost via the outflow. Inputs of ${ }^{137} \mathrm{Cs}$ during the period of deployment of the sediment traps $(2012 / 13)$ are estimated to be around $5.2 \times 10^{4} \mathrm{kBq}$ year $^{-1}$, or $294 \mathrm{~Bq} \mathrm{~m}^{-2}$ year $^{-1}$ per unit area of the lake, significantly higher than the fluxes on sedimenting particles recorded by the sediment traps (Table 3) of between $46 \mathrm{~Bq} \mathrm{~m}^{-2}$ year $^{-1}$ (Trap A) and $33 \mathrm{~Bq} \mathrm{~m}^{-2}$ year $^{-1}$ (Trap B). The discrepancy can be accounted for by supposing that more than $80 \%$ of the ${ }^{137} \mathrm{Cs}$ entering the water column exits the lake via the outflow, partly on particulates but mainly in the aqueous phase. This is supported by the sediment core results. Whereas cumulative inputs of ${ }^{137} \mathrm{Cs}$ to Brotherswater (allowing for radioactive decay) up to the end of 1976/77 are estimated to have been around $5.2 \times 10^{6} \mathrm{kBq}$, or $28,800 \mathrm{~Bq} \mathrm{~m}^{-2}$, measured inventories in cores collected from Brotherswater at that time (Eakins et al. 1981, 1984, ESM4) ranged from $5013 \mathrm{~Bq} \mathrm{~m}^{-2}$ to $8272 \mathrm{~Bq} \mathrm{~m}^{-2}$. The 1989 and 2011/16

Table 5 Cumulative inputs of ${ }^{137} \mathrm{Cs}$ to the water column of Brotherswater, and to the sediment record

\begin{tabular}{llll}
\hline & $\begin{array}{l}\text { Total inputs } \\
\mathrm{Bq} \mathrm{m}^{-2}\end{array}$ & $\begin{array}{l}\text { Sediment record } \\
\mathrm{Bq} \mathrm{m}^{-2}\end{array}$ & Ratio (\%) \\
\hline $1976 / 77$ & 28,880 & 4713 & 16 \\
$1988 / 89$ & 35,811 & 6120 & 17 \\
$2011 / 16$ & 29,160 & 3712 & 13 \\
\hline
\end{tabular}


studies yielded similar results. Table 5 shows modelled values of the cumulative inputs of ${ }^{137} \mathrm{Cs}$ up to the time of each study, and estimates of the mean inventories stored in the sediment record at those times determined from the relevant cores. From these data it is estimated that no more than around $15 \%$ of ${ }^{137} \mathrm{Cs}$ entering the water column is delivered to the sediment record. This is consistent with the value determined from Eqs. (4) and (5). Assuming a value of $f_{D}=0.3$ for the fraction of ${ }^{137} \mathrm{Cs}$ on particulates, a water residence time of 12 days, and a particle settling time of 17 days, the residence time of ${ }^{137} \mathrm{Cs}$ in the water column of Brotherswater is calculated to be 10 days, and the retention fraction $\mathcal{F}_{C s}$ (the fraction of ${ }^{137} \mathrm{Cs}$ entering the water column retained in the sediment record) to be $18 \%$. These results are further supported by the calculations of the Chernobyl ${ }^{137} \mathrm{Cs}$ inventory in the 1988/9 sediment cores, the mean value of which was estimated to be less than $700 \mathrm{~Bq} \mathrm{~m}^{-2}$ from a fallout of $4000 \mathrm{~Bq} \mathrm{~m}^{-2}$ just 2-3 years earlier.

\section{Conclusion}

In spite of many large uncertainties, mainly associated with the difficulty in determining the precise impact of large flood events, the results presented here confirm earlier results that in lakes with large catchments, a significant proportion of fallout ${ }^{210} \mathrm{~Pb}$ and ${ }^{137} \mathrm{Cs}$ (and presumably other atmospheric contaminants) entering the water column consists of older material that may have been deposited some years earlier on the catchment. Catchment transport is estimated to account for $67 \%$ of ${ }^{210} \mathrm{~Pb}$ inputs to Brotherswater, a little higher than the figure for Blelham Tarn (47\%), perhaps reflecting the relatively larger catchment at Brotherswater. Although substantial it is significantly lower than the 93\% suggested in the earlier study by Eakins et al. (1981, 1984). It does however amount to no more than $2.4 \%$ of annual fallout onto the catchment. According to the model used here this fraction is determined by the catchment/lake transport parameter $k$ (Eq. 9). Its calculated value at Brotherswater $\left(0.0024\right.$ year $\left.^{-0.5}\right)$ is similar to the value for Blelham Tarn $\left(0.0022\right.$ year $\left.^{-0.5}\right)$ in spite of the relatively larger catchment.

The fraction of ${ }^{210} \mathrm{~Pb}$ entering the water column transferred to the sediment record is largely controlled by the water residence time, lake depth and suspended sediment particle size. Because of the short water residence time a relatively large fraction $(53 \%)$ of the ${ }^{210} \mathrm{~Pb}$ inputs at Brotherswater is lost via the outflow, with just $47 \%$ entering the sediment record. The significantly higher fraction $(75 \%)$ entering the sediment record at Blelham Tarn can be attributed to its longer residence time in the water column. At both sites, a comparison between the modelled and empirical values suggests that ${ }^{210} \mathrm{~Pb}$ is mainly transported on relatively fine particulates with a mean particle size of around 3-4 $\mu \mathrm{m}$. Their relatively slow removal from the water column does however allow them to be transported relatively uniformly throughout the lake.

The sediment trap results highlight the extent to which significant quantities of ${ }^{137} \mathrm{Cs}$ deposited on the catchment of Brotherswater continue to be transported to the lake 30 years after the last fallout. The catchment/lake transport parameter for ${ }^{137} \mathrm{Cs}$ was estimated to be 0.0043 year $^{-0.5}$, significantly higher than the value for ${ }^{210} \mathrm{~Pb}$ but lower than the value for ${ }^{137} \mathrm{Cs}$ at Blelham Tarn $\left(0.0060\right.$ year $\left.^{-0.5}\right)$. Because of the higher proportion of ${ }^{137} \mathrm{Cs}$ in the essentially aqueous phase (passing a $0.45 \mu \mathrm{m}$ filter) a much greater fraction of ${ }^{137} \mathrm{Cs}$ entering the water column was lost via the outflow, with only about a sixth being retained in the sediment record. Although catchment inputs soon exceeded direct inputs from the atmosphere, their impact was to delay the date of peak inputs to the lake by no more than one or 2 years. The results do however highlight the potential importance of the catchment pathway in interpreting sediment records of atmospheric pollution, particularly in lakes with large catchments.

The complexity of the relationship between atmospheric fallout and sediment records is of particular relevance to ${ }^{210} \mathrm{~Pb}$ in view of its widespread use for dating these natural archives. This is highlighted in the results presented in Semertzidou et al. (2019). These showed that in parts of the lake heavily impacted by catchment inputs the simple ${ }^{210} \mathrm{~Pb}$ dating models are not necessarily applicable and may need to be applied in a piecewise way using chronostratigraphic dates as reference points. In areas of the lake not so affected the simple models gave good results except where the record was disturbed e.g.by local slump events.

Open Access This article is distributed under the terms of the Creative Commons Attribution 4.0 International License (http:// creativecommons.org/licenses/by/4.0/), which permits 
unrestricted use, distribution, and reproduction in any medium, provided you give appropriate credit to the original author(s) and the source, provide a link to the Creative Commons license, and indicate if changes were made.

\section{References}

Appleby PG (1997) Sediment records of fallout radionuclides and their application to studies of sediment-water interactions. Water Air Soil Pollut 99:573-586

Appleby PG, Oldfield F (1978) The calculation of lead-210 dates assuming a constant rate of supply of unsupported ${ }^{210} \mathrm{~Pb}$ to the sediment. Catena $5: 1-8$

Appleby PG, Nolan PJ, Gifford DW, Godfrey MJ, Oldfield F, Anderson NJ, Battarbee RW (1986) Pb-210 dating by lowbackground gamma counting. Hydrobiologia 143:21-27

Appleby PG, Richardson N, Nolan PJ (1992) Self-absorption corrections for well-type germanium detectors. Nucl Instrum Methods B 71:228-233

Appleby PG, Haworth EY, Michel H, Short DB, Laptev G, Piliposian GT (2003) The transport and mass balance of fallout radionuclides in Blelham Tarn, Cumbria (UK). J Paleolimnol 29:459-473

Benoit G, Hemond HF (1987) A biogeochemical mass balance of ${ }^{210} \mathrm{Po}$ and ${ }^{210} \mathrm{~Pb}$ in an oligotrophic lake with seasonally anoxic hypolimnion. Geochim Cosmochim Acta 51: $1445-1456$

Bloesch J, Burns N (1980) A critical review of sedimentation trap technique. Schweiz Z Hydrol 42(1):15-55

Bonnett PJP, Appleby PG, Haworth EY, Hilton J, Davison W, Oldfield F (1992) Environmental behaviour of radioactivity from Chernobyl: Brotherswater study. DOE Report No. DOE/RAS/92.004

Boyle JF (1995) A simple closure mechanism for a compact, large-diameter, gravity corer. J Paleolimnol 13:85-87

Cambray RS, Playford K, Lewis GNJ, Carpenter RC (1989) Radioactive fallout in air and rain: results to the end of 1987. AERE-R 13226, Harwell

Cawse PA, Horrill AD (1986) A survey of 137Cs and Pu in British Soils in 1977. AERE-R 10155, Harwell, HMSO, London

Chambers KC (1978) Source-sediment relationship in the Cumbrian lakes. Ph.D. thesis, University of Reading

Dominik J, Burrus D, Vernet JP (1987) Transport of environmental radionuclides in an alpine watershed. Earth Planet Sci Lett 84:165-180

Eakins JD, Cambray RS, Chambers KC, Lally AE (1981) The transfer of natural and artificial radionuclides to Brotherswater from its catchment. AERE-R 10375, AERE Harwell, UK

Eakins JD, Cambray RS, Chambers KC, Lally AE (1984) The transfer of natural and artificial radionuclides to Brotherswater from its catchment. In: Haworth EY, Lund JW (eds) Lake sediments and environmental history. Leicester University Press, Leicester, pp 94-114

Hilton J, Haworth EY, Davison W, Kelly M, Hamilton-Taylor J, Appleby PG (1992) Transport processes of ${ }^{137} \mathrm{Cs}$ in lake environments. DOE/RW/92.005
Maberly SS, De Ville MM, Thackeray SS, Feuchtmayr H, Fletcher JM, James JB, Kelly JL, Vincent CD, Winfield IJ, Newton A, Atkinson D, Croft A, Drew H, Saag M, Taylor S, Titterington $H$ (2011) A survey of the lakes of the English Lake District: The Lakes Tour 2010. NERC/Centre for Ecology \& Hydrology, 137pp. (CEH ProjectNumber: C04357)

Met Office (2006) MIDAS: UK daily rainfall data. NCAS British atmospheric data centre. http://catalogue.ceda.ac.uk/ uuid/c732716511d3442f05cdeccbe99b8f90. Accessed 12 Dec 2018

Monte L, Klyashtorin AI, Strebl F, Bossew P, Aggarwal P (2002) Radionuclide transport in freshwater systems: A synthesis of the results of the CRP. IAEA-TECDOC-1314 Radionuclide transport dynamics in freshwater resources. IAEA, Vienna, pp 5-34

Pennington W (1981) Records of a lake's life in time: the sediments. Hydrobiologia 79:197-215

Perks MT, Warburton J, Bracken L (2013) Critical assessment and validation of a time-integrating fluvial suspended sediment sampler. Hydrol Process 28(17):4795-4807

Robbins JA (1978) Geochemical and geophysical applications of radioactive lead. In: Nriagu JO (ed) Biogeochemistry of lead in the environment. Elsevier Scientific, Amsterdam, pp 285-393

Sansone U, Belli M, Voitsekovitch OV, Kanivets VV (1996) ${ }^{137} \mathrm{Cs}$ and ${ }^{90} \mathrm{Sr}$ in water and suspended particulate matter of the Dnieper river-reservoirs system (Ukraine). Sci Total Environ 186:257-271

Schillereff DN, Chiverrell RC, Macdonald N, Hooke JM (2016a) Hydrological thresholds and basin control over paleoflood records in lakes. Geology 44:43-46. https://doi. org/10.1130/G37261.1

Schillereff DN, Chiverrell RC, Macdonald N, Hooke JM, Welsh KE (2016b) Quantifying system disturbance and recovery from historical mining-derived metal contamination at Brotherswater, Northwest England. J Paleolimnol 56:205-221. https://doi.org/10.1007/s10933-016-9907-1

Schillereff DN, Chiverrell RC, Macdonald N, Hooke JM, Welsh KE, Piliposian G, Croudace IW (2019) Convergent human and climate forcing of late-Holocene flooding in Northwest England. Glob Planet Change 182:102998

Semertzidou P, Piliposian GT, Chiverrell RC, Appleby PG (2019) Long-term stability of records of fallout radionuclides in the sediments of Brotherswater, Cumbria (UK). J Paleolimnol 61:231-249. https://doi.org/10.1007/ s10933-018-0055-7

Smith FB, Clarke MJ (1989) The transport and deposition of airborne debris from the Chernobyl nuclear power plant accident with special emphasis on the consequences to the United Kingdom. Meteorological Office Scientific Paper. 42

Smith JT, Appleby PG, Hilton J, Richardson N (1997) Inventories and fluxes of ${ }^{210} \mathrm{~Pb},{ }^{137} \mathrm{Cs}$ and ${ }^{241} \mathrm{Am}$ determined from the soils of three small catchments in Cumbria, UK. J Environ Radioact 37:127-142

Publisher's Note Springer Nature remains neutral with regard to jurisdictional claims in published maps and institutional affiliations. 